Portland State University

PDXScholar

$12-2016$

\title{
Investigating CO2 Removal by Ca- and Mg-based Sorbents with Application to Indoor Air Treatment
}

\author{
Elliott T. Gall \\ Portland State University, gall@pdx.edu \\ Cem Sonat \\ Nanyang Technological University, Singapore \\ William W. Nazaroff \\ University of California - Berkeley \\ Cise Unluer \\ Nanyang Technological University, Singapore
}

Follow this and additional works at: https://pdxscholar.library.pdx.edu/mengin_fac

Part of the Materials Science and Engineering Commons, and the Mechanical Engineering Commons Let us know how access to this document benefits you.

\section{Citation Details}

Gall, E. T., Sonat, C., Nazaroff, W. W., \& Unluer, C. (2016). Investigating CO2 removal by Ca- and Mg-based sorbents with application to indoor air treatment. Building \& Environment, 110161-172. doi:10.1016/ j.buildenv.2016.10.008

This Post-Print is brought to you for free and open access. It has been accepted for inclusion in Mechanical and Materials Engineering Faculty Publications and Presentations by an authorized administrator of PDXScholar. Please contact us if we can make this document more accessible: pdxscholar@pdx.edu. 


\section{Accepted Manuscript}

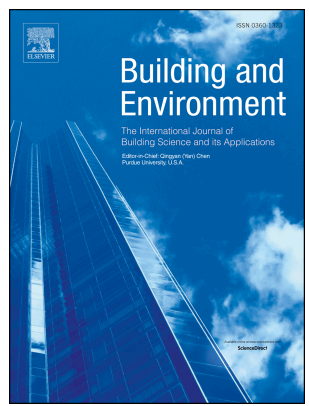

Investigating $\mathrm{CO}_{2}$ removal by $\mathrm{Ca}$ - and $\mathrm{Mg}$-based sorbents with application to indoor air treatment

Elliott T. Gall, Cem Sonat, William W. Nazaroff, Cise Unluer

PII: $\quad$ S0360-1323(16)30399-7

DOI: $\quad$ 10.1016/j.buildenv.2016.10.008

Reference: BAE 4667

To appear in: Building and Environment

Received Date: 16 August 2016

Revised Date: 14 October 2016

Accepted Date: 15 October 2016

Please cite this article as: Gall ET, Sonat C, Nazaroff WW, Unluer C, Investigating $\mathrm{CO}_{2}$ removal by Caand Mg-based sorbents with application to indoor air treatment, Building and Environment (2016), doi: 10.1016/j.buildenv.2016.10.008.

This is a PDF file of an unedited manuscript that has been accepted for publication. As a service to our customers we are providing this early version of the manuscript. The manuscript will undergo copyediting, typesetting, and review of the resulting proof before it is published in its final form. Please note that during the production process errors may be discovered which could affect the content, and all legal disclaimers that apply to the journal pertain. 
Investigating $\mathrm{CO}_{2}$ removal by $\mathrm{Ca}$ - and $\mathrm{Mg}$-based sorbents with application to indoor air treatment

Elliott T. Gall ${ }^{1,2,3}$, Cem Sonat ${ }^{2}$, William W Nazaroff ${ }^{3,4}$, Cise Unluer ${ }^{2 \cdot *}$

\author{
${ }^{1}$ Mechanical and Materials Engineering, Portland State University, Portland, OR 97201, USA
} ${ }^{2}$ Civil and Environmental Engineering, Nanyang Technological University, Singapore ${ }^{3}$ Berkeley Education Alliance for Research in Singapore, 1 Create Way, 138602, Singapore

${ }^{4}$ Civil and Environmental Engineering Department, University of California, Berkeley, CA * Corresponding author. Tel.: +65 91964970, E-mail address: ucise@ntu.edu.sg

\section{Abstract}

Indoor carbon dioxide $\left(\mathrm{CO}_{2}\right)$ levels serve as an indicator of ventilation sufficiency in relation to metabolic effluents. Recent evidence suggests that elevated $\mathrm{CO}_{2}$ exposure (with or without other bioeffluents) may cause adverse cognitive effects. In shelter-in-place (SIP) facilities, indoor $\mathrm{CO}_{2}$ levels may become particularly elevated. This study evaluates four low-cost alkaline earth metal oxides and hydroxides as $\mathrm{CO}_{2}$ sorbents for potential use in indoor air cleaning applications. Sorbents studied were $\mathrm{MgO}, \mathrm{Mg}(\mathrm{OH})_{2}, \mathrm{Ca}(\mathrm{OH})_{2}$ and commercially available soda lime. Uncarbonated sorbents characterized with nitrogen adsorption porosimetry showed BET surface areas in the $5.6-27 \mathrm{~m}^{2} / \mathrm{g}$ range. Microstructural analyses, including X-ray diffraction, thermogravimetric analysis and scanning electron microscopy confirmed the carbonation mechanisms and extent of sorption under environmental conditions typical of indoor spaces. Ca-based sorbents demonstrated higher extent of carbonation than Mg-based sorbents. Laboratory parameterizations, including rate constants $(k)$ and carbonation yields $(y)$, were applied in material balance models to assess the $\mathrm{CO}_{2}$ removal potential of Ca-based sorbents in three types of indoor environments. Soda lime $\left(k=[2.2-3.6] \times 10^{-3} \mathrm{~m}^{3} \mathrm{~mol}\right.$ $\mathrm{CO}_{2}^{-1} \mathrm{~h}^{-1}, y=0.49-0.51$ ) showed potential for effective use in SIP facilities. For example, $\mathrm{CO}_{2}$ exposure in a modeled SIP facility could be reduced by $80 \%$ for an 8 -h sheltering interval and to levels below $5000 \mathrm{ppm}$ for an 8-h period with a practically sized air cleaner. Predicted effectiveness was more modest for bedrooms and classrooms. 
Keywords: Ventilation, bioeffluents, air cleaning, indoor air pollution, sorption

\section{Introduction}

Excluding emissions from unvented combustion, carbon dioxide $\left(\mathrm{CO}_{2}\right)$ concentrations in occupied indoor spaces depend on three main factors: the $\mathrm{CO}_{2}$ emission rate from human metabolism, the outdoor $\mathrm{CO}_{2}$ concentration, and the outdoor air ventilation rate. Indoor $\mathrm{CO}_{2}$ levels are primarily managed through the replacement of indoor air with outdoor air. However, providing outdoor air ventilation for buildings, while necessary to achieve indoor air quality objectives, can contribute substantially to building energy use [1]. Decreasing the outdoor air exchange rate is one strategy to reduce the energy demand of buildings, as mechanical ventilation requires energy input to fans and may contribute to heating, cooling, and dehumidification needs, depending on site- and time-specific environmental conditions. However, reducing outdoor air-exchange rates tends to increase the concentrations of indoor-generated air pollutants, including $\mathrm{CO}_{2}$. Indoor $\mathrm{CO}_{2}$ levels may also become elevated when building operation is altered temporarily (e.g. when air exchange is minimized to protect occupants from hazardous outdoor conditions) including events that precipitate the need for a shelter-in-place (SIP) response [2].

Carbon dioxide, a primary product of human metabolism, is often used as a proxy for indooremitted air pollutants $[3,4]$. It is generally not considered harmful at levels routinely encountered in buildings. Rather, high levels of indoor $\mathrm{CO}_{2}$ imply that ventilation is insufficient to adequately dilute air pollutants emitted by occupants or other indoor sources. However, some emerging evidence suggests that exposure to elevated $\mathrm{CO}_{2}$ at levels commonly encountered indoors may adversely affect human cognition [5-7]. The matter is not yet resolved; other recent studies imply that other bioeffluents or possibly some combination of $\mathrm{CO}_{2}$ and other bioeffluents may be the causative agents [8-12]. 
threshold. One specific motivation for this study is that a household SIP facility is mandatory in Singapore in all government constructed housing built after 1998 [13]. This requirement is noteworthy as government housing in Singapore provides accommodation for approximately $85 \%$ of the country's population [14]. A prior investigation of SIP habitability in the US context showed that $\mathrm{CO}_{2}$ levels could reach 16,000 ppm after $3 \mathrm{~h}$ of occupancy by five persons [15]. Exposure to such levels could result in acute health consequences, as evidenced by studies investigating exposures in spacecraft that show adverse effects including lethargy, malaise, and headache at $\mathrm{CO}_{2}$ concentrations between 4,000 and $10,000 \mathrm{ppm}$ [16]. Studies supporting the OSHA PEL showed electrolyte imbalances, metabolic changes, and non-narcotic central nervous system effects for short-term exposures to $\mathrm{CO}_{2}$ in the range $10,000-30,000$ ppm $[16,17]$.

Given the common occurrence of elevated $\mathrm{CO}_{2}$ concentrations in certain indoor spaces combined with the possibility of acute health effects in SIP facilities and cognitive decrements in other settings, this study investigates the possibility of controlling indoor $\mathrm{CO}_{2}$ via active removal by means of low-cost solid sorbents that could be integrated into a recirculating indoor air cleaner. Capture of $\mathrm{CO}_{2}$ with solid sorbents is an emerging area of research with promising potential for future lower cost approaches for $\mathrm{CO}_{2}$ control [18], including the application of sorbents that are derived from waste materials [19]. Solid sorbents such as metal oxides and hydroxides are considered promising candidates for removing $\mathrm{CO}_{2}$ from flue gases through carbonation during which oxides or hydroxides are converted into stable carbonates $[20,21]$. Sorbents under development for use in carbon capture from fossil fuel combustion typically target operation at higher temperatures (on the order of $400{ }^{\circ} \mathrm{C}$ or greater) and at elevated $\mathrm{CO}_{2}$ levels (up to the order of $10 \%)$, although approaches for room temperature operation at outdoor ambient $\mathrm{CO}_{2}$ levels have also been reported $[22,23]$.

During the carbonation process, gaseous $\mathrm{CO}_{2}$ dissolves in water, becoming carbonic acid, which neutralizes the hydroxides (e.g. portlandite $\left(\mathrm{Ca}(\mathrm{OH})_{2}\right)$ or brucite $\left.\left(\mathrm{Mg}(\mathrm{OH})_{2}\right)\right)$. Two main factors control the rate and degree of carbonation of $\mathrm{CaO}$ and/or $\mathrm{MgO}$ and their derivatives: (i) sorbent 
composition (chemical and physical properties of the solid components, water content and presence of additives) and (ii) environmental conditions $\left(\mathrm{CO}_{2}\right.$ concentration and pressure, relative humidity $(\mathrm{RH})$, temperature and duration) [24-28]. The main factors influencing the carbonation of $\mathrm{Ca}$ - or $\mathrm{Mg}$ based sorbents can be summarized as the transport of $\mathrm{CO}_{2}$ to the sorbent surface and its reactivity with the sorbent. Transport is affected by environmental conditions (i.e. air pressure, $\mathrm{CO}_{2}$ concentration, and abundance of water, etc.) and the pore structure of the sorbent, whereas the sorbent composition and material properties influence its reactivity. In the case of Mg-based sorbents, the hydration of $\mathrm{MgO}$ leads to the formation of magnesium hydroxide (brucite, $\mathrm{Mg}(\mathrm{OH})_{2}$ ). In the presence of sufficient water, brucite reacts with $\mathrm{CO}_{2}$, leading to the formation of hydrated magnesium carbonates such as nesquehonite $\left(\mathrm{MgCO}_{3} \cdot 3 \mathrm{H}_{2} \mathrm{O}\right)$, hydromagnesite $\left(4 \mathrm{MgCO}_{3} \cdot \mathrm{Mg}(\mathrm{OH})_{2} \cdot 4 \mathrm{H}_{2} \mathrm{O}\right)$, dypingite $\left(4 \mathrm{MgCO}_{3} \cdot \mathrm{Mg}(\mathrm{OH})_{2} \cdot 5 \mathrm{H}_{2} \mathrm{O}\right)$ and artinite $\left(\mathrm{Mg}_{2} \mathrm{CO}_{3} \cdot \mathrm{Mg}(\mathrm{OH})_{2} \cdot 3 \mathrm{H}_{2} \mathrm{O}\right)$ [29-33]. Higher $\mathrm{CO}_{2}$ concentrations increase the rate and degree of carbonation at initial stages [24]. The presence of water within the sorbent plays an important role in the degree of hydration and carbonation as the initial water content both facilitates the hydration and carbonation reactions and influences the rate of $\mathrm{CO}_{2}$ diffusion through the sorbent system. In dry $\mathrm{CO}_{2}$ scrubbing, low water content present in sorbent media and low RH in air surrounding the sorbent delay the carbonation reaction, whereas an increase in the water content of the media speeds the carbonation reaction but results in a decrease of $\mathrm{CO}_{2}$ diffusion since the diffusivity of $\mathrm{CO}_{2}$ is much slower in water than it is in air (i.e. the diffusion coefficient of $\mathrm{CO}_{2}$ is $16 \mathrm{~mm}^{2} / \mathrm{s}$ in air vs. $0.0016 \mathrm{~mm}^{2} / \mathrm{s}$ in water [34]). Therefore, rapid sorption kinetics require sufficient water for hydration and subsequent carbonation but not so much water as to interfere with rapid diffusion of $\mathrm{CO}_{2}$ through the sorbent system. Previous studies have shown that $\mathrm{RH}$ values in the approximate range $40-80 \%$ are preferable for increased carbonation of the $\mathrm{Mg}$ and $\mathrm{Ca}$ oxides [35-37]. The rates of diffusion of $\mathrm{CO}_{2}$ into the sorbent matrix and its subsequent interaction with $\mathrm{Ca}$ and $\mathrm{Mg}$ are of interest in this study. to control $\mathrm{CO}_{2}$ concentrations in locations such as SIP facilities and other indoor locations where $\mathrm{CO}_{2}$ 
levels may be temporarily elevated. Apart from SIP environments, other potentially attractive locations are those where specific populations spend substantial proportions of their day in conditions that may not always be sufficiently ventilated, such as bedrooms overnight and classrooms during the day [38]. Several recent efforts further describe the potential and opportunity of $\mathrm{CO}_{2}$ capture techniques specifically suited for built environments [39-41]. This study employs a range of experimental methods to characterize the physico-chemical properties and carbonation products, kinetics and yields of four alkaline earth metal oxides and their hydroxides. Also provided is an estimate of the efficacy of potentially promising sorbents when integrated into a standalone air cleaner under three hypothetical scenarios. Cases considered are those in which active $\mathrm{CO}_{2}$ removal may be beneficial owing to one or more of these factors: high occupant density, small room volume, low air-exchange rate, and a susceptible population. Three specific cases are explored: (i) SIP facilities in residential environments, (ii) sleeping microenvironments, and (iii) school classrooms.

\section{Materials and Methods}

\subsection{Sorbents}

A commercial $\mathrm{CO}_{2}$ solid sorbent, SodaSorb (Grace Chemical), consisting of a mixture of $\mathrm{Ca}(\mathrm{OH})_{2}, \mathrm{H}_{2} \mathrm{O}, \mathrm{NaOH}$ and $\mathrm{KOH}$, was purchased from Advanced Marine Pte Ltd, Singapore. The performance of this sorbent was compared to three other products: MgO (commercial name “calcined magnesite 92/200") obtained from Richard Baker Harrison Ltd (UK) and high purity (>95\%) $\mathrm{Ca}(\mathrm{OH})_{2}$ and $\mathrm{Mg}(\mathrm{OH})_{2}$ purchased from Aik Moh Paints \& Chemicals, Singapore.

Particle size distributions of three sorbents $\left(\mathrm{MgO}, \mathrm{Ca}(\mathrm{OH})_{2}\right.$ and $\left.\mathrm{Mg}(\mathrm{OH})_{2}\right)$, in the form received from the manufacturer, were measured with a particle size analyzer (Mastersizer 2000, Malvern). Particle size of the sorbents is reported as the $d_{50}$, or mass median particle size. The internal physical properties of the four sorbents were measured via nitrogen adsorption porosimetry conducted at $77 \mathrm{~K}$ (Quantachrome Quadrasorb). All four samples were ground to a fine powder in a mortar and pestle prior to analysis to facilitate outgassing of samples and equilibration with $\mathrm{N}_{2}$ 
partial pressure during adsorption or desorption cycles. Note that this results in the reporting of a

specific surface area, or the interior surface area normalized by mass. It is possible that transport limitations will reduce the 'effective' surface area below the specific surface areas reported if sorbents are implemented with larger grain size than the fine powders used in $\mathrm{N}_{2}$ adsorption

before measuring nitrogen adsorption isotherms. Surface areas of the sorbents were determined by applying Quantachrome's BET theory; their cumulative pore volumes and average pore sizes were determined with Quantachrome's density functional theory.

\subsection{Characterizing $\mathrm{CO}_{2}$ uptake on sorbents}

142

\subsubsection{Carbonation of sorbents}

The four sorbents were subjected to carbonation in a controlled laboratory apparatus as shown in Figure 1. Compressed laboratory air was first passed through a membrane dryer that included a 0.01 micron pre-filter (Laman MD-15LS and Laman SAM350-E, Air Parts Center Pte Ltd) to remove water vapor and particulate matter present in laboratory air. Dry air was then passed through an activated carbon packed bed (BPL $6 \times 16$, Calgon Carbon). The outlet flow was split to control the humidity level, with one stream passing through a washing column filled with deionized water. The flow rates through the dry and humidified air streams were regulated using mass flow controllers (Omega FMA5500, Omega Singapore). In parallel, a small flow supplied from a compressed gas cylinder of food-grade $\mathrm{CO}_{2}$ (>99\% purity) was injected into the main flow to achieve the desired $\mathrm{CO}_{2}$ concentration set-point. The two flow streams were combined and directed to a temperature controlled enclosure (KBE3.1, Binder $\mathrm{GmBH}$ ). Inlet and outlet $\mathrm{CO}_{2}$, temperature and $\mathrm{RH}$ (Teleaire 7001, Onset Computer Corporation) were measured upstream and downstream of a reaction chamber that was either a washing column loaded with a specific sorbent/water ratio or a packed bed reactor loaded with dry sorbent. 
A calibration curve was developed between the two $\mathrm{CO}_{2}$ monitors by collocating the monitors and recording responses at five $\mathrm{CO}_{2}$ levels ranging between 0 and $2500 \mathrm{ppm}$. The resulting linear equation was applied to adjust the readings of the downstream $\mathrm{CO}_{2}$ monitor. observe carbonation while minimizing limitations to $\mathrm{CO}_{2}$ uptake that may result from the availability of $\mathrm{H}_{2} \mathrm{O}$. These experiments are subsequently referred to according to experimental conditions. For example, experiment 'MgO-0.1-2.7-2200' refers to the carbonation of the sorbent $\mathrm{MgO}$ at a loading rate of $0.1 \mathrm{~g}$ (sorbent)/g $\left(\mathrm{H}_{2} \mathrm{O}\right)$, flow rate of $2.7 \mathrm{~L} / \mathrm{min}$, and inlet $\mathrm{CO}_{2}$ concentration of $2200 \mathrm{ppm}$. Carbonated sorbent products were extracted from the column, centrifuged to separate the sorbent from residual water and dried for 48 hours under low $\mathrm{RH}$ in a temperature/ $\mathrm{RH}$ controlled chamber ( $\mathrm{T}$ $\left.=20^{\circ} \mathrm{C}, \mathrm{RH}<10 \%\right)$. Sorbents that exhibited effective carbonation during the 7-day tests were selected for further analysis to characterize uptake kinetics and reaction yields. Sorbents were tested under dry and slurry conditions. Dry experiments were conducted with a loading of $5 \mathrm{~g}$ of media placed on a wire mesh under a constant inlet $\mathrm{RH}$ of $75 \%$. Slurry experiments were conducted at a loading ratio of $0.03 \mathrm{~g}$ sorbent/g water in a total volume of $100 \mathrm{~cm}^{3}$. Both dry and slurry experiments were conducted at two flow rates: 1.8 and $2.7 \mathrm{~L} / \mathrm{min}$. These flow rates correspond to contact times of 0.28 and 0.18 seconds, respectively, in dry experiments and 0.45 and 0.3 seconds, respectively, in slurry experiments. All experiments were conducted at $25{ }^{\circ} \mathrm{C}$. Inlet and outlet temperature, $\mathrm{RH}$ and $\mathrm{CO}_{2}$ levels were measured at five-minute intervals. Each experiment was conducted until the sample appeared to be fully carbonated under the set conditions, defined as when the 1-h running average inlet and outlet $\mathrm{CO}_{2}$ concentrations were equal to within $\pm 25 \mathrm{ppm}$. 
outlet $\mathrm{CO}_{2}$ monitors across the duration of an experiment to determine the total mass of $\mathrm{CO}_{2}$

removed. This mass of $\mathrm{CO}_{2}$ uptake was divided by the initial mass of sorbent and converted to moles

to determine the molar yield, $y$ (mol sorbed $\mathrm{CO}_{2} / \mathrm{mol}$ sorbent initially present). For soda lime, the

estimate of moles of sorbent was made from the mass of only $\mathrm{Ca}(\mathrm{OH})_{2}$, as the $\mathrm{KOH}$ and $\mathrm{NaOH}$ served coupled equations describing the time-varying quantities of $\mathrm{CO}_{2}$ and unreacted sorbent in the reactor. The model equations and procedures employed to estimate $k$ and $y$ are provided in the Supporting Information; Figure S1 illustrates results for a sample experimental run.

\subsubsection{Microstructural analysis}

Selected samples from the 7-day $\mathrm{CO}_{2}$ uptake experiments were stored in acetone for at least

7 days to stop hydration, followed by vacuum drying for another 7 days in preparation for X-ray diffraction (XRD), thermogravimetric analysis (TGA) and scanning electron microscopy (SEM) analyses. The vacuum-dried samples were ground to a powder fine enough to pass through a $75 \mu \mathrm{m}$ sieve before they were analyzed under XRD and TGA. The XRD measurements, aimed to determine the crystallinity of compounds and identify and distinguish between different phases within the samples, were made on a Philips PW 1800 spectrometer using $\mathrm{Cu} \mathrm{K}_{\alpha}$ radiation (40 kV, $30 \mathrm{~mA}$ ) with a scanning rate of $0.04^{\circ} 2 \theta /$ step from 5 to $55^{\circ} 2 \theta$. TGA was conducted on a Perkin Elmer TGA 4000 instrument using a temperature range from 50 to $900{ }^{\circ} \mathrm{C}$ with a heating rate of $10{ }^{\circ} \mathrm{C} / \mathrm{min}$ under nitrogen flow. The vacuum-dried samples were mounted onto aluminum stubs using double-sided adhesive carbon disks and coated with gold before SEM analysis. The SEM analysis was carried out with a Zeiss Evo 50 microscope to investigate the morphologies of the hydration and carbonation products within the prepared samples. 


\subsection{Modeling $\mathrm{CO}_{2}$ removal in three indoor environments}

Laboratory sorbent characterization results were used as inputs into material-balance models to conduct a scaling analysis of the efficacy of hypothetical deployments of stand-alone $\mathrm{CO}_{2}$ scrubbers in three types of indoor environments where $\mathrm{CO}_{2}$ concentrations are routinely elevated: shelter-in-place (SIP) facilities [15,44], bedrooms [14,45] and classrooms [46]. Model inputs describing indoor spaces and occupancy were selected to be generally representative of such environments in the Singapore context, as summarized in Table 1. Room volume and occupancy levels for the SIP facility ( $5 \mathrm{~m}^{3}$ for 2 persons) were calculated considering measurements made in a typical Singaporean apartment and Singapore regulations that stipulate a minimum of $1.8 \mathrm{~m}^{3}$ of shelter volume per occupant [47]. Note that regulations recommend greater SIP volume than the stipulated minimum for increased comfort during an emergency. Room volume for the bedroom was based on measurements of a recently constructed ( $<5$ y old) 3 -bedroom apartment that is a typical Singapore residence; volume and occupancy levels of classrooms were taken from a study of six primary school classrooms in Singapore [46]. Emission rates of $\mathrm{CO}_{2}$ were made following the procedure described by Persily et al. [48], with assumptions as described in Table 1 annotations.

Ventilation flow rates in the bedroom and SIP environments were determined from the average value of triplicate measurements of air exchange rates calculated from the decay of $\mathrm{CO}_{2}$ that was injected into an unoccupied bedroom and household shelter. Ventilation flow rates in the classroom environment were taken as the average of $\mathrm{CO}_{2}$ tracer decay measurement results made in six unoccupied, air-conditioned classrooms in primary schools in Singapore [46]. In bedrooms and classrooms, windows and doors were sealed during measurements to reflect a 'low flow' condition where the exchange of indoor and outdoor air is intentionally reduced to minimize intrusion of warm, humid outdoor air into the buildings. In the SIP facility, measurements were made in a typical household shelter and, per peacetime requirements dictated in the Singapore building code, the ventilation sleeve was opened to $25 \%$ of the total sleeve area [47]. During an emergency, the sleeve 
would be fully closed, likely reducing the air exchange rate in the household shelter to a value lower than that reported here.

The efficacy of an air cleaner containing a $\mathrm{CO}_{2}$-removing sorbent was evaluated for the three hypothetical indoor environments by solving coupled material balance equations written for (i) the concentration of $\mathrm{CO}_{2}$ in the room, (ii) the concentration of $\mathrm{CO}_{2}$ through a packed bed of sorbent and (iii) the quantity of the unreacted sorbent in the air cleaner. These equations are presented in the Supporting Information. Modeling of indoor environments was conducted for practically sized air cleaners considering the mass of media, volume of air cleaner, and resulting pressure drop across the packed media bed. Rates of carbonation were assumed to remain constant as total pressure varied across the modeled packed bed. Prior studies indicate that total pressure influences uptake but only for orders of magnitude higher changes in total pressure than are relevant in the present context [49]. Flow rates through a hypothetical air cleaner were selected to maintain air-media contact times for dry sorbents that matched those used in experiments described in §2.2.1. Scrubber dimensions were selected to allow the contact time to be held constant while providing a volumetric flow rate similar to commercial air cleaners appropriately sized for the indicated indoor microenvironment.

\section{Results and Discussion}

\subsection{Physicochemical properties of sorbents}

Physical and chemical properties of the four sorbents considered in this investigation are shown in Table 2. The $\mathrm{MgO}, \mathrm{Mg}(\mathrm{OH})_{2}$, and $\mathrm{Ca}(\mathrm{OH})_{2}$ materials represent pure or nearly pure compounds that are commercially available, low-cost, and may be derived from waste streams [19]. A stream for reusing alkaline earth metal oxides or hydroxides that simultaneously addresses an indoor air quality concern could represent a valuable opportunity. The fourth sorbent considered, soda lime, is mainly $\mathrm{Ca}(\mathrm{OH})_{2}$; however, it is specifically designed for $\mathrm{CO}_{2}$ scrubbing by the addition of (a) two catalysts $(\mathrm{KOH}, \mathrm{NaOH})$ and (b) approximately $10 \% \mathrm{H}_{2} \mathrm{O}$ to accelerate the uptake of $\mathrm{CO}_{2}$ and subsequent conversion of $\mathrm{Ca}(\mathrm{OH})_{2}$ to $\mathrm{CaCO}_{3}$. The physical properties summarized in Table 2 reveal 
only modest variation in properties across the four sorbents. The measured mass median particle sizes $\left(\mathrm{d}_{50}\right)$ of the three powder samples $\left(\mathrm{MgO}, \mathrm{Mg}(\mathrm{OH})_{2}\right.$, and $\left.\mathrm{Ca}(\mathrm{OH})_{2}\right)$ ranged between 5 and $19 \mu \mathrm{m}$, whereas the grain size for the soda lime media was reported as $1 \mathrm{~mm}$ (by the manufacturer). Particle size distributions for the powder samples are provided in Figure S2 of the Supporting Information. Note that in the subsequent modeling of indoor spaces, granular media with a $d_{50}$ of $1 \mathrm{~mm}$ is assumed for both soda lime and $\mathrm{Ca}(\mathrm{OH})_{2}$; the implications of this assumption for the modeling of a hypothetical $\mathrm{Ca}(\mathrm{OH})_{2}$ packed bed are discussed in $\S 3.3$. The specific surface areas of these materials are a few orders of magnitude lower than values for other engineered sorbents for $\mathrm{CO}_{2}$ and gasphase pollutants, such as metal organic frameworks [50,51]. Among the four sorbents considered, $\mathrm{MgO}$ has the highest internal surface area, $28 \mathrm{~m}^{2} / \mathrm{g}$, a factor of five higher than the value for pure $\mathrm{Mg}(\mathrm{OH})_{2}$. Increasing specific surface area may present a useful pathway for enhancing the uptake of $\mathrm{CO}_{2}$ to low-cost sorbents, as it is probable that the availability of $\mathrm{CO}_{2}$ sorption and/or reaction sites is a factor that limits uptake of $\mathrm{CO}_{2}$.

\subsection{Characterizing $\mathrm{CO}_{2}$ uptake by sorbents}

\subsubsection{X-ray diffraction}

XRD patterns of Ca- and Mg-based sorbents subjected to a flow rate of $2.7 \mathrm{~L} / \mathrm{min}$ under a constant $\mathrm{CO}_{2}$ concentration of 2200 ppm for 7 days are shown in Figures 2 (a) and (b), respectively. Sorbents containing $\mathrm{Ca}(\mathrm{OH})_{2}$ and soda lime indicate the formation of the carbonation product calcite, whose main peak is observed at $29.4^{\circ} 2 \theta$ along with several secondary peaks. The absence of the major hydroxide phase portlandite $\left(\mathrm{Ca}(\mathrm{OH})_{2}\right)$ in the presented patterns is a clear indication that the prepared samples have fully carbonated during the 7 days of exposure. As these samples were subjected to accelerated carbonation conditions under an elevated $\mathrm{CO}_{2}$ concentration and flow rate, the hydroxide phases within the soda lime and $\mathrm{Ca}(\mathrm{OH})_{2}$ based sorbents have been transformed into calcite, as observed in the XRD patterns.

The crystalline phases forming after the carbonation of Mg-based sorbents are shown in Figure 2(b). In addition to magnesium carbonate, some of the common carbonation products 
observed were hydrated magnesium carbonates (HMCs) such as dypingite and hydromagnesite.

Dypingite (powder diffraction file (PDF) \#029-0857) has its four highest intensity peaks at $15^{\circ}, 30.4^{\circ}$, peaks and many of the weaker ones can be seen in the XRD patterns presented, confirming the presence of dypingite. Hydromagnesite (PDF \#025-0513) has its highest intensity peaks at $15.3^{\circ}$, XRD spectra. Hydromagnesite (PDF \#003-0093) also has sharp peaks in the high-angle region at $42^{\circ}$ and $45.5^{\circ} 2 \theta$, where small peaks can be seen in the presented diffractograms. These peaks confirm the presence of hydromagnesite in the samples.

Other than the carbonation products, the presence of brucite is observed in both samples, where unhydrated $\mathrm{MgO}$ peaks can be seen in the MgO-based sorbent. The presence of the $\mathrm{MgO}$ peak at $42.9^{\circ} 2 \theta$ indicates incomplete hydration, whereas the brucite peak at $38^{\circ} 2 \theta$ is an indication of incomplete carbonation of both samples. These results clearly indicate that the carbonation conditions utilized in this study were not sufficient for the Mg-based samples to fully carbonate within the given exposure period. In principle, improved carbonation could be realized via (i) the use of a higher reactivity MgO with a larger specific surface area to increase the rate and degree of hydration and the subsequent carbonation process and (ii) optimization of the carbonation conditions to increase the rate and amount of $\mathrm{CO}_{2}$ diffusion within the samples.

\subsubsection{Thermogravimetric analysis}

The TGA results for the Ca- and Mg-based sorbents are shown in Figure 3(a) and (b), respectively. As can be seen in Figure 3(a), the thermal decomposition of Ca-based sorbents followed a regular pattern, indicating the decomposition of the main carbonate phase, calcite. This decomposition occurred between temperatures of 650 and $830^{\circ} \mathrm{C}$ as expected, resulting in a weight loss of about $44 \%$ in both samples. Corroborating the XRD results, this outcome shows that both samples have fully carbonated as the molar mass calculations of the carbonation reaction indicate that $\mathrm{CO}_{2}(44 \mathrm{~g} / \mathrm{mol})$ represents $44 \%$ of the overall mass of calcite $(100 \mathrm{~g} / \mathrm{mol})$. The similar 
decarbonation behavior and weight loss of soda lime and $\mathrm{Ca}(\mathrm{OH})_{2}$-based samples is a clear indication that they demonstrated similar carbonation capabilities notwithstanding the additives (i.e. $\mathrm{NaOH}$ and $\mathrm{KOH}$ ) included in the commercial soda lime sorbent. phases with different decomposition patterns. According to the weight lost shown in the TGA curves, the decomposition steps of Mg-based samples can be divided into 3 main stages, whose details are listed in Table 3: (i) $<300{ }^{\circ} \mathrm{C}$ : loss of unbound water and water of crystallization of HMCs associated with their dehydration; (ii) $300-500{ }^{\circ} \mathrm{C}$ : dehydroxylation of HMCs and decomposition of any uncarbonated brucite; and (iii) $>500{ }^{\circ} \mathrm{C}$ : decarbonation process involving the decomposition of HMCs into MgO.

The two endothermic peaks corresponding to the loss of unbound water and dehydration of water bonded to HMCs were observed at $\sim 120$ and $250^{\circ} \mathrm{C}$, respectively. A strong endothermic peak reflecting the decomposition of uncarbonated brucite accompanied by the dehydroxylation of HMCs (hydromagnesite and dypingite) was observed at $\sim 450{ }^{\circ} \mathrm{C}$. This transformation was followed by a broader peak corresponding to the decarbonation of HMCs at $\sim 680^{\circ} \mathrm{C}$. The similar decomposition patterns and final weights demonstrated by the $\mathrm{MgO}$ and $\mathrm{Mg}(\mathrm{OH})_{2}$ samples clearly indicate their comparable extents of carbonation. The presence of the large brucite peak within both samples is a clear indication of incomplete carbonation, which was in agreement with the XRD patterns.

\subsubsection{Scanning electron microscopy}

Figure 4 shows the microstructures of the 4 samples analyzed by XRD and TGA. The SEM images of the soda lime (Figure 4(a) and (b)) and $\mathrm{Ca}(\mathrm{OH})_{2}$-based samples (Figure 4(c) and (d)) reveal similar morphologies at both magnifications. The formation of tightly packed calcite crystals of different sizes can be observed in both samples. Hexagonal calcite crystals are accompanied by sparsely distributed crystals of acicular shape in the $\mathrm{Ca}(\mathrm{OH})_{2}$ based sample, as shown in Figure 4 (c). 
In general, both samples indicate a dense formation of calcite, in agreement with the results of the TGA and XRD analyses.

As depicted in Figure 4(e)-(h), the microstructure of $\mathrm{MgO}$ and $\mathrm{Mg}(\mathrm{OH})_{2}$ based samples are dominated with rosette-like formations of brucite, as was indicated by the TGA and XRD analyses. The main difference between the two samples is the size and density of brucite formations. The direct hydration of $\mathrm{MgO}$ results in the dense formation of brucite particles that are fused into large agglomerates. The direct inclusion of $\mathrm{Mg}(\mathrm{OH})_{2}$ produces a porous distribution of brucite particles with smaller sizes. However, the morphology of these brucite formations did not influence their carbonation potential as both samples demonstrated similar carbonation behaviours and capacities. Minor formations of hydromagnesite and dypingite are observed around the brucite crystals, which is a clear indication of limited carbonation within these samples.

\subsubsection{Kinetics and capacity of $\mathrm{CO}_{2}$ uptake by Ca-based sorbents}

This section describes the results of the uptake experiments for the Ca-containing sorbents. The Mg-containing sorbents did not sufficiently carbonate under the experimental conditions to justify characterizing their kinetic and yield parameters. Some combination of catalysis (as in the case of soda lime) or alteration of physical parameters (e.g., increasing the specific surface area) would be required to increase the kinetics and capacity such that $\mathrm{MgO}$ or $\mathrm{Mg}(\mathrm{OH})_{2}$ based sorbents may be considered effective for $\mathrm{CO}_{2}$ removal under conditions relevant to indoor environments.

Experimental conditions, rate constants and carbonation yields for soda lime and pure $\mathrm{Ca}(\mathrm{OH})_{2}$ are reported in Table 4. Rate constants and yields are generally higher for soda lime than for $\mathrm{Ca}(\mathrm{OH})_{2}$, which is as expected given the presence of two catalysts plus water in soda lime to facilitate the carbonation reaction. Under dry conditions (i.e., for solid sorbents with inlet airflow at $75 \% \mathrm{RH}$ ), low yields were determined for $\mathrm{Ca}(\mathrm{OH})_{2}$. As will be further explored in $\S 3.3$, these limitations constrain the effectiveness of dry $\mathrm{Ca}(\mathrm{OH})_{2}$ as a $\mathrm{CO}_{2}$ sorbent under representative indoor conditions. However, when the experimental flow rate was increased from 1.8 to $2.8 \mathrm{~L} / \mathrm{min}$, the reaction rate of $\mathrm{CO}_{2}$ with $\mathrm{Ca}(\mathrm{OH})_{2}$ increased to nearly that of soda lime, albeit with substantially lower yield. This 
increase in kinetics illustrates potential for subsequent optimization of air cleaners utilizing $\mathrm{Ca}(\mathrm{OH})_{2}$ media in indoor air treatment applications.

We explored the role of water availability by conducting experiments in both slurry and packed dry-bed configurations. Under slurry conditions, the carbonation yield for $\mathrm{Ca}(\mathrm{OH})_{2}$ is substantially higher than for dry-bed conditions, approaching that of soda lime. A slurry configuration is likely infeasible for indoor air cleaning applications owing to high pressure drops across a water column and the high-humidity effluent. However, future research could be worthwhile to pursue, investigating in more detail the role of water or water vapor influencing the uptake of $\mathrm{CO}_{2}$ by Ca-containing sorbents with the goal of increasing $\mathrm{CO}_{2}$ removal rates on low-cost sorbents.

\subsection{Modeling indoor $\mathrm{CO}_{2}$ removal}

Modeled indoor $\mathrm{CO}_{2}$ concentrations for the three hypothetical scenarios (SIP, bedroom, and classroom settings) are shown in Figure 5 . In each case, a duration of $8 \mathrm{~h}$ is simulated, to approximate a single-event occupancy in each of the three types of spaces. In this section, results for $\mathrm{CO}_{2}$ removal for 8-h model durations are described for each scenario, focusing on conditions that result in greater observed removal of $\mathrm{CO}_{2}$ from the hypothetical indoor environments. A sensitivity analysis is then presented for the most efficacious scenario. Finally, implications of model results regarding feasibility of $\mathrm{Ca}(\mathrm{OH})_{2}$ as a reagent for indoor $\mathrm{CO}_{2}$ removal are discussed. illustrates the most efficacious outcome among the scenarios considered. This favorable result is a consequence of the small volume and relatively low air exchange rate of the modeled SIP facility. For the SIP scenario with a soda lime containing air cleaner, the $\mathrm{CO}_{2}$ level is maintained below $5000 \mathrm{ppm}$ until 7-8.5 $\mathrm{h}$ after initial occupancy. After $10 \mathrm{~h}$ of operation, the soda lime packed bed is effectively spent (see Figures S4-S6 of the Supporting Information), and the $\mathrm{SIP} \mathrm{CO}_{2}$ concentration begins to increase, exceeding 10,000 ppm shortly after $10 \mathrm{~h}$ of occupancy (see Figure S4). These times contrast with the no air cleaning case, where the $5000 \mathrm{ppm} \mathrm{CO}$ level is reached after only $1.1 \mathrm{~h}$ of sheltering 
and $10,000 \mathrm{ppm}$ is reached after only $1.9 \mathrm{~h}$. Without air cleaning, concentrations of $\mathrm{CO}_{2}$ in the SIP environment would reach values in excess of $25,000 \mathrm{ppm}$ after $8 \mathrm{~h}$ of occupancy. These results imply that occupancy under the "no scrubber" condition shown in Figure 5 for more than a few hours may result in $\mathrm{CO}_{2}$ exposures that can produce acute adverse health effects [17].

Bedrooms represent an important microenvironment contributing to daily exposures of $\mathrm{CO}_{2}$, as shown in a recent study of personal exposures to $\mathrm{CO}_{2}$ in Singapore [52]. As can be observed in Figure 5 , in the absence of air cleaning, levels of $\mathrm{CO}_{2}$ in the bedroom scenario exceed $1000 \mathrm{ppm}$ after just $1 \mathrm{~h}$ of exposure. An air cleaner containing a soda lime packed bed, operating either at low or high flow rate, can maintain sub-1000 ppm $\mathrm{CO}_{2}$ concentrations in the bedroom for the duration of the 8-h sleeping period. As with the SIP scenario, an air cleaner containing a pure $\mathrm{Ca}(\mathrm{OH})_{2}$ dry sorbent appears to have more modest impacts on indoor $\mathrm{CO}_{2}$ concentrations. However, worth noting is that the average $\mathrm{CO}_{2}$ concentration during the 8-h sleeping period for the high flow rate $\mathrm{Ca}(\mathrm{OH})_{2}$ treatment is approximately $950 \mathrm{ppm}$.

In the case of classrooms, due to the larger room volume and higher air exchange rate than the bedroom and SIP scenarios, the presence of the air-treatment unit has a relatively small impact on $\mathrm{CO}_{2}$ concentrations. Levels of $\mathrm{CO}_{2}$ in the classroom after $8 \mathrm{~h}$ of operation in absence of air cleaning would be approximately $1400 \mathrm{ppm}$, compared to a range $900-1050 \mathrm{ppm}$ with a soda lime air cleaner. Since a classroom would not typically be occupied continuously for 8-h periods, the $\mathrm{CO}_{2}$ concentrations presented in Figure 5 for the classroom case may be considered as an upper limit. Given the modest reductions in classroom $\mathrm{CO}_{2}$ levels for a substantial mass of media and volume of air cleaner (see Table 1), the results indicate that the classroom scenario described here does not appear to present a good opportunity for active $\mathrm{CO}_{2}$ removal given the present state of sorbent development.

Model runs for longer durations $(16 \mathrm{~h}, 40 \mathrm{~h}$, and $40 \mathrm{~h}$, respectively, in the SIP, bedroom, and classroom) assuming continuous occupancy are shown in Figure S3 (Supporting Information) with pertinent results of the sensitivity analysis summarized in Table 5. Removal of $\mathrm{CO}_{2}$ under the 
conditions of the SIP facility occurs over a range of achievable pressure drops (150-435 Pa) when compared with commercially available air cleaners. Because of the small volume and low air exchange rate, impacts of air cleaning on $\mathrm{CO}_{2}$ concentrations are substantial: the time to reach a $10,000 \mathrm{ppm}$ threshold is extended by 4-12 hours, and cumulative 8-h exposures are reduced by 60$90 \%$. However, the relatively small mass of media combined with the high $\mathrm{CO}_{2}$ concentrations results in substantial media usage; in all cases the scrubber media is exhausted after $13 \mathrm{~h}$ of continuous operation.

In the bedroom scenario, the scrubber appears effective over the range of media masses considered, with pressure drops ranging from 120-290 Pa. Reductions in cumulative exposures are again substantial, in the range $50-66 \%$, and at higher sorbent masses appear to exhibit cumulative run-times that are $40 \mathrm{~h}$ or greater. Note that these estimates are conservative, as an air-cleaner deployed to a bedroom would not operate continuously for $40 \mathrm{~h}$, and would likely be utilized in sequential 8-h periods that begin with $\mathrm{CO}_{2}$ concentration nearer to ambient levels. Model results for a $\mathrm{Ca}(\mathrm{OH})_{2}$ containing air cleaner across all three scenarios illustrate more modest removal of $\mathrm{CO}_{2}$ from the indoor space than for soda lime. While the cost of $\mathrm{Ca}(\mathrm{OH})_{2}$ itself is relatively low and the efficacy of the air cleaner could be increased by recirculating air at higher flow rates through the $\mathrm{Ca}(\mathrm{OH})_{2}$ bed, effectively increasing the removal rate of $\mathrm{CO}_{2}$ could become prohibitive with respect to energy use owing to the nonlinear relationship between flow rate and pressure drop. Also worth noting is that the estimates of $k$ and $y$ for $\mathrm{Ca}(\mathrm{OH})_{2}$ are likely best-case values with respect to room-scale air cleaning. The $\mathrm{Ca}(\mathrm{OH})_{2}$ used in laboratory parameterizations was purchased from a commercial supplier and was of a finer grain than the granular media that would typically be used in an air cleaner; transport limitations resulting from the geometry of a 437 larger $\mathrm{Ca}(\mathrm{OH})_{2}$ granule may reduce the effective yield, rate constant or both, possibly a result of the 438 formation of a diffusion limiting carbonate shell [53]. Achieving the uptake reported from laboratory 439 tests in the applied scenarios by use of a fine grain $\mathrm{Ca}(\mathrm{OH})_{2}$ may, in practice, create prohibitively 440 large pressure drops across the air cleaner. Testing granular $\mathrm{Ca}(\mathrm{OH})_{2}$ with varying physical 
441 properties, including size of particles as deployed in the packed bed, would more fully inform the

442 potential use of $\mathrm{Ca}(\mathrm{OH})_{2}$ as a low cost sorbent for active indoor $\mathrm{CO}_{2}$ control.

\section{Conclusions}

This study investigated the ability of Mg- and Ca-based sorbents to take up gaseous carbon dioxide through the formation of solid carbonates. The work establish links between a range of controlling parameters and the progress of carbonation through a sorbent matrix. Four alkaline earth metal oxides or hydroxides were characterized for their potential as $\mathrm{CO}_{2}$ sorbents in an active indoor air cleaning application. A comparison between Mg- and Ca-based sorbents was provided in terms of carbonation degree, microstructure and parameterizations of carbonation kinetics and yields from laboratory experiments. These results were supported by XRD, TGA and SEM analyses, which provided information on the hydration and carbonation phases, the progress and degree of carbonation and the morphology of the sorbents.

Results indicate that extensive carbonation of sorbents occurred at conditions typical of indoor spaces $\left(25^{\circ} \mathrm{C}\right.$ and $\mathrm{CO}_{2}$ levels of approximately $2200 \mathrm{ppm}$ ), although Mg-containing sorbents carbonated slowly such that parameterization of kinetics and capacity were not pursued. Modeling of hypothetical scenarios in which packed beds of sorbents were part of an active indoor air cleaner show potential for the substantial removal of $\mathrm{CO}_{2}$ from SIP facilities with the use of soda lime. Reductions in integrated $\mathrm{CO}_{2}$ exposures of over $80 \%$ are predicted and indoor $\mathrm{CO}_{2}$ levels are maintained below the OSHA PEL for an assumed 8-h period of occupancy. These reductions were accomplished with reasonable masses of soda lime $(1.7 \mathrm{~kg}$ ) and at a pressure drop (approximately $300 \mathrm{~Pa}$ ) achievable by fans similar to those present in a typical HEPA filter-containing portable air cleaner. Modeling for low-ventilation bedrooms showed that meaningful reductions are also possible in this setting, with reductions in $\mathrm{CO}_{2}$ levels after 8 hours of occupancy from $2500 \mathrm{ppm}$ (with no air cleaner) to $550-750 \mathrm{ppm}$ for a continuously operating soda-lime containing air cleaner. However, regular occupancy in bedrooms would necessitate the weekly replacement of the sorbent media as the model shows nearly full exhaustion of the media after 40 hours of operation. The 
relatively large mass of sorbent needed in bedrooms could make the use of soda lime costprohibitive, a disadvantage that could potentially be removed by enhancing the kinetics and capacity of the lower cost sorbents $\left(\mathrm{Ca}(\mathrm{OH})_{2}, \mathrm{MgO}\right.$ and $\left.\mathrm{Mg}(\mathrm{OH})_{2}\right)$. The empirical kinetic and yield findings were supported by detailed microstructural and thermal analyses, which enabled a thorough comparison of the different media studied. Mg-based sorbents experienced low carbonation rates in the conditions utilized in this study. The carbonation of Mg-based sorbents could be further enhanced via the use of a higher reactivity MgO with a larger specific surface area to induce hydration and the subsequent carbonation process and optimization of the carbonation conditions to increase the rate and amount of $\mathrm{CO}_{2}$ diffusion within the samples. Efforts to develop sorbents tailored for $\mathrm{CO}_{2}$ removal in conditions typical of indoor spaces could 477 enable practical utilization of new methods of removing $\mathrm{CO}_{2}$ from indoor spaces, which appear 478 especially promising in special circumstances where increasing air exchange is infeasible owing to 479 adverse outdoor conditions, such as shelter-in-place facilities.

\section{Acknowledgements}

481 This work was supported by the Republic of Singapore's National Research Foundation through a grant to the Berkeley Education Alliance for Research in Singapore (BEARS) for the Singapore- 
486

487

488

489

490

491

492

493

494

495

496

497

498

499

500

501

502

503

504

505

506

507

508

509

510

511

512

513

514

515

516

517

518

519

520

521

522

523

524

525

526

527

528

529

530

531

532

533

534

[1] M.W. Liddament, M. Orme, Energy and ventilation, Appl. Therm. Eng. 18 (1998) 1101-1109. doi:10.1016/S1359-4311(98)00040-4.

[2] W.R. Chan, W.W. Nazaroff, P.N. Price, A.J. Gadgil, Effectiveness of urban shelter-in-place-I: Idealized conditions, Atmos. Environ. 41 (2007) 4962-4976.

doi:10.1016/j.atmosenv.2007.01.041.

[3] J. Sundell, H. Levin, W.W. Nazaroff, W.S. Cain, W.J. Fisk, D.T. Grimsrud, F. Gyntelberg, Y. Li, A.K. Persily, A.C. Pickering, J.M. Samet, J.D. Spengler, S.T. Taylor, C.J. Weschler, Ventilation rates and health: multidisciplinary review of the scientific literature, Indoor Air. 21 (2011) 191-204. doi:10.1111/j.1600-0668.2010.00703.x.

[4] E.T. Richardson, C.D. Morrow, D.B. Kalil, L.-G. Bekker, R. Wood, Shared air: A renewed focus on ventilation for the prevention of tuberculosis transmission, PLoS ONE. 9 (2014) e96334. doi:10.1371/journal.pone.0096334.

[5] U. Satish, M.J. Mendell, K. Shekhar, T. Hotchi, D. Sullivan, S. Streufert, W.J. Fisk, Is $\mathrm{CO}_{2}$ an indoor pollutant? Direct effects of low-to-moderate $\mathrm{CO}_{2}$ concentrations on human decisionmaking performance, Environ. Health Perspect. 120 (2012) 1671-1677. doi:10.1289/ehp.1104789.

[6] T. Vehviläinen, H. Lindholm, H. Rintamäki, R. Pääkkönen, A. Hirvonen, O. Niemi, J. Vinha, High indoor $\mathrm{CO}_{2}$ concentrations in an office environment increases the transcutaneous $\mathrm{CO}_{2}$ level and sleepiness during cognitive work, J. Occup. Environ. Hyg. 13 (2016) 19-29. doi:10.1080/15459624.2015.1076160.

[7] J.G. Allen, P. MacNaughton, U. Satish, S. Santanam, J. Vallarino, J.D. Spengler, Associations of cognitive function scores with carbon dioxide, ventilation, and volatile organic compound exposures in office workers: A controlled exposure study of green and conventional office environments, Environ. Health Perspect. 124 (2016) 805-812. doi:10.1289/ehp.1510037.

[8] P. Strøm-Tejsen, D. Zukowska, P. Wargocki, D.P. Wyon, The effects of bedroom air quality on sleep and next-day performance, Indoor Air. (2015). doi:10.1111/ina.12254.

[9] R. Maddalena, M.J. Mendell, K. Eliseeva, W.R. Chan, D.P. Sullivan, M. Russell, U. Satish, W.J. Fisk, Effects of ventilation rate per person and per floor area on perceived air quality, sick building syndrome symptoms, and decision-making, Indoor Air. 25 (2015) 362-370. doi:10.1111/ina.12149.

[10] X. Zhang, P. Wargocki, Z. Lian, Physiological responses during exposure to carbon dioxide and bioeffluents at levels typically occurring indoors, Indoor Air. (2016). doi:10.1111/ina.12286.

[11] X. Zhang, P. Wargocki, Z. Lian, C. Thyregod, Effects of exposure to carbon dioxide and bioeffluents on perceived air quality, self-assessed acute health symptoms and cognitive performance, Indoor Air. (2016). doi:10.1111/ina.12284.

[12] X. Zhang, P. Wargocki, Z. Lian, Human responses to carbon dioxide, a follow-up study at recommended exposure limits in non-industrial environments, Build. Environ. 100 (2016) 162171. doi:10.1016/j.buildenv.2016.02.014.

[13] Singapore Civil Defence Force, Household Shelters, (2014). https://www.scdf.gov.sg/content/scdf_internet/en/building-professionals/cdshelter/household-shelters.html (accessed May 23, 2016).

[14] S.C. Sekhar, S.E. Goh, Thermal comfort and IAQ characteristics of naturally/mechanically ventilated and air-conditioned bedrooms in a hot and humid climate, Build. Environ. 46 (2011) 1905-1916. doi:10.1016/j.buildenv.2011.03.012.

[15] J.J. Jetter, C. Whitfield, Effectiveness of expedient sheltering in place in a residence, J. Hazard. Mater. 119 (2005) 31-40. doi:10.1016/j.jhazmat.2004.11.012.

[16] J. Law, S. Watkins, D. Alexander, In-flight carbon dioxide exposures and related symptoms: association, susceptibility, and operational implications, NASA/TP-2010-216126, Hanover, MD: NASA Center for AeroSpace Information, June 2010. 
[17] U.S. Department of Labor, Code of Federal Regulations, n.d. Air contaminants Title 29, Part 1910.1000-1910.145 www.osha.gov (accessed August 1, 2016).

[18] J. Wang, L. Huang, R. Yang, Z. Zhang, J. Wu, Y. Gao, Q. Wang, D. O'Hare, Z. Zhong, Recent advances in solid sorbents for $\mathrm{CO}_{2}$ capture and new development trends, Energy Environ. Sci. 7 (2014) 3478-3518. doi:10.1039/C4EE01647E.

[19] T.T.N. Bachelor, P. Toochinda, Development of low-cost amine-enriched solid sorbent for $\mathrm{CO}_{2}$ capture, Environ. Technol. 33 (2012) 2645-2651. doi:10.1080/09593330.2012.673014.

[20] L. Di Felice, $\mathrm{CO}_{2}$ Capture by $\mathrm{CaO}$-based sorbents and sorption enhanced reaction systems, in: S.L. Suib (Ed.), New and Future Developments in Catalysis: Actication of Carbon Dioxide, Elsevier, Amsterdam, 2013: pp. 603-625. http://www.sciencedirect.com/science/article/pii/B978044453882600022X (accessed January 8, 2015).

[21] K.J. Fricker, A.-H.A. Park, Effect of $\mathrm{H}_{2} \mathrm{O}$ on $\mathrm{Mg}(\mathrm{OH})_{2}$ carbonation pathways for combined $\mathrm{CO}_{2}$ capture and storage, Chem. Eng. Sci. 100 (2013) 332-341. doi:10.1016/j.ces.2012.12.027.

[22] F.S. Zeman, K.S. Lackner, Capturing carbon dioxide directly from the atmosphere., World Resour. Rev. 16 (2004) 157-172.

[23] J. Zhang, R. Singh, P.A. Webley, Alkali and alkaline-earth cation exchanged chabazite zeolites for adsorption based $\mathrm{CO}_{2}$ capture, Microporous Mesoporous Mater. 111 (2008) 478-487. doi:10.1016/j.micromeso.2007.08.022.

[24] C. Unluer, A. Al-Tabbaa, Enhancing the carbonation of $\mathrm{MgO}$ cement porous blocks through improved curing conditions, Cem. Concr. Res. 59 (2014) 55-65. doi:10.1016/j.cemconres.2014.02.005.

[25] P.J. Davies, B. Bubela, The transformation of nesquehonite into hydromagnesite, Chem. Geol. 12 (1973) 289-300. doi:10.1016/0009-2541(73)90006-5.

[26] E. Königsberger, L.-C. Königsberger, H. Gamsjäger, Low-temperature thermodynamic model for the system $\mathrm{Na}_{2} \mathrm{CO}_{3}-\mathrm{MgCO}_{3}-\mathrm{CaCO}_{3}-\mathrm{H}_{2} \mathrm{O}$, Geochim. Cosmochim. Acta. 63 (1999) 3105-3119. doi:10.1016/S0016-7037(99)00238-0.

[27] L. Marini, Geological sequestration of carbon dioxide: Thermodynamics, kinetics, and reaction path modeling, Elsevier (2007).

[28] Y. Xiong, A.S. Lord, Experimental investigations of the reaction path in the $\mathrm{MgO}-\mathrm{CO}_{2}-\mathrm{H}_{2} \mathrm{O}$ system in solutions with various ionic strengths, and their applications to nuclear waste isolation, Appl. Geochem. 23 (2008) 1634-1659. doi:10.1016/j.apgeochem.2007.12.035.

[29] M. Hänchen, V. Prigiobbe, R. Baciocchi, M. Mazzotti, Precipitation in the Mg-carbonate system-effects of temperature and $\mathrm{CO}_{2}$ pressure, Chem. Eng. Sci. 63 (2008) 1012-1028. doi:10.1016/j.ces.2007.09.052.

[30] M.A. Shand, The Chemistry and Technology of Magnesia, Wiley, (2006). http://ca.wiley.com/WileyCDA/WileyTitle/productCd-0471656038.html (accessed June 28, 2016).

[31] C. Unluer, A. Al-Tabbaa, Characterization of light and heavy hydrated magnesium carbonates using thermal analysis, J. Therm. Anal. Calorim. 115 (2013) 595-607. doi:10.1007/s10973-0133300-3.

[32] C. Unluer, A. Al-Tabbaa, Impact of hydrated magnesium carbonate additives on the carbonation of reactive MgO cements, Cem. Concr. Res. 54 (2013) 87-97. doi:10.1016/j.cemconres.2013.08.009.

[33] C. Unluer, A. Al-Tabbaa, The role of brucite, ground granulated blastfurnace slag, and magnesium silicates in the carbonation and performance of $\mathrm{MgO}$ cements, Constr. Build. Mater. 94 (2015) 629-643. doi:10.1016/j.conbuildmat.2015.07.105.

[34] CRC Handbook of Chemistry and Physics, 93rd Edition, CRC Press. (2012). https://www.crcpress.com/CRC-Handbook-of-Chemistry-and-Physics-93rdEdition/Haynes/p/book/9781439880494 (accessed June 28, 2016). 
[35] D.A. Torres-Rodríguez, H. Pfeiffer, Thermokinetic analysis of the $\mathrm{MgO}$ surface carbonation process in the presence of water vapor, Thermochim. Acta. 516 (2011) 74-78. doi:10.1016/j.tca.2011.01.021.

[36] A.V. Saetta, B.A. Schrefler, R.V. Vitaliani, 2 - D model for carbonation and moisture/heat flow in porous materials, Cem. Concr. Res. 25 (1995) 1703-1712. doi:10.1016/0008-8846(95)001662.

[37] S.K. Roy, K.B. Poh, D. O. Northwood, Durability of concrete-accelerated carbonation and weathering studies, Build. Environ. 34 (1999) 597-606. doi:10.1016/S0360-1323(98)00042-0.

[38] E.T. Gall, A. Chen, V.W.-C. Chang, W.W. Nazaroff, Exposure to particulate matter and ozone of outdoor origin in Singapore, Build. Environ. 93, Part 1 (2015) 3-13. doi:10.1016/j.buildenv.2015.03.027.

[39] T.S. Lee, J.H. Cho, S.H. Chi, Carbon dioxide removal using carbon monolith as electric swing adsorption to improve indoor air quality, Build. Environ. 92 (2015) 209-221. doi:10.1016/j.buildenv.2015.04.028.

[40] E.T. Gall, W.W. Nazaroff, New directions: Potential climate and productivity benefits from $\mathrm{CO}_{2}$ capture in commercial buildings, Atmos. Environ. 103 (2015) 378-380. doi:10.1016/j.atmosenv.2015.01.004.

[41] M.K. Kim, L. Baldini, H. Leibundgut, J.A. Wurzbacher, N. Piatkowski, A novel ventilation strategy with $\mathrm{CO}_{2}$ capture device and energy saving in buildings, Energy Build. 87 (2015) 134-141. doi:10.1016/j.enbuild.2014.11.017.

[42] B. Al-Shaikh, S. Stacey, Essentials of Anaesthetic Equipment, $4^{\text {th }}$ edition, Elsevier Health Sciences, 2013.

[43] J. Morrison, G. Jauffret, F.P. Glasser, J.L. Galvez-Martos, M.S. Imbabi, Towards carbon negative cements, in: University of Sheffield, 2014.

[44] A.K. Persily, H. Davis, S.J. Emmerich, W.S. Dols, Airtightness evaluation of shelter-in-place spaces for protection against airborne chembio releases, Report EPA/600/R-09/051, US Environmental Protection Agency (2009).

[45] G. Bekö, T. Lund, F. Nors, J. Toftum, G. Clausen, Ventilation rates in the bedrooms of 500 Danish children, Build. Environ. 45 (2010) 2289-2295. doi:10.1016/j.buildenv.2010.04.014.

[46] A. Chen, E.T. Gall, V.W.C. Chang, Indoor and outdoor particulate matter in primary school classrooms with fan-assisted natural ventilation in Singapore, Environ. Sci. Pollut. Res. (2016). doi:10.1007/s11356-016-6826-7.

[47] Building Construction Authority, Technical requirements for household shelters 2012, Singapore Building Construction Authority, Singapore, 2012.

https://www.bca.gov.sg/HouseholdShelters/others/Technical_Requirements_For_HS_2012.pd $f$ (accessed April 10, 2016).

[48] A.K. Persily, Evaluating building IAQ and ventilation with indoor carbon dioxide, ASHRAE Trans. 103 (1997) 193-204.

[49] F.-C. Yu, L.-S. Fan, Kinetic study of high-pressure carbonation reaction of calcium-based sorbents in the calcium looping process (CLP), Ind. Eng. Chem. Res. 50 (2011) 11528-11536. doi:10.1021/ie200914e.

[50] O.K. Farha, I. Eryazici, N.C. Jeong, B.G. Hauser, C.E. Wilmer, A.A. Sarjeant, R.Q. Snurr, S.T. Nguyen, A.Ö. Yazaydın, J.T. Hupp, Metal-organic framework materials with ultrahigh surface areas: Is the sky the limit?, J. Am. Chem. Soc. 134 (2012) 15016-15021. doi:10.1021/ja3055639.

[51] K. Sumida, D.L. Rogow, J.A. Mason, T.M. McDonald, E.D. Bloch, Z.R. Herm, T.-H. Bae, J.R. Long, Carbon dioxide capture in metal-organic frameworks, Chem. Rev. 112 (2012) 724-781. doi:10.1021/cr2003272.

[52] E.T. Gall, T. Cheung, I. Luhung, S. Schiavon, W.W. Nazaroff, Real-time monitoring of personal exposures to carbon dioxide, Build. Environ. 104 (2016) 59-67. doi:10.1016/j.buildenv.2016.04.021. 
636

637

638

639

640

641

642

643
[53] D.P. Butt, K.S. Lackner, C.H. Wendt, S.D. Conzone, H. Kung, Y.-C. Lu, J.K. Bremser, Kinetics of thermal dehydroxylation and carbonation of magnesium hydroxide, J. Am. Ceram. Soc. 79 (1996) 1892-1898. doi:10.1111/j.1151-2916.1996.tb08010.x.

[54] E.T. Gall, V.W.C. Chang, W.W. Nazaroff, Controlling indoor $\mathrm{CO}_{2}$ with a solid sorbent: Kinetics and capacity, in: Proc. 1st North Am. Reg. Conf. Healthy Build., Boulder, CO, 2015: pp. 474477.

[55] S. Ergun, Fluid flow through packed columns, Chem. Eng. Prog. 48 (1952) 89-94. 


\section{ACCEPTED MANUSCRIPT}

Table 1. Summary of model inputs to three scenarios considered for active $\mathrm{CO}_{2}$ removal ${ }^{\mathrm{a}}$

\begin{tabular}{llll}
\hline Building and air cleaner parameters & Shelter-in-place & Bedroom & Classroom \\
\hline Room volume, $V\left(\mathrm{~m}^{3}\right)$ & 5 & 50 & 150 \\
Occupancy (\# of persons) & 2 & 2 & 40 \\
$\mathrm{CO}_{2}$ emission rate, $E(\mathrm{~mol} \mathrm{CO} / \mathrm{h})^{\mathrm{a}}$ & 1.4 & 1.4 & 19 \\
Outdoor air ventilation, $Q\left(\mathrm{~m}^{3} / \mathrm{h}\right)$ (Air & $1(0.2)$ & $15(0.3)$ & $450(3)$ \\
exchange rate, $\left(\mathrm{h}^{-1}\right)$ ) & & & \\
Air cleaner flow rate, low/high $\mathrm{Q}_{\mathrm{f}}\left(\mathrm{m}^{3} / \mathrm{h}\right)$ & $13 / 21$ & $40 / 61$ & $198 / 306$ \\
Packed bed diameter $(\mathrm{m})$ & 0.15 & 0.25 & 0.45 \\
Packed bed length $(\mathrm{m})$ & 0.11 & 0.12 & 0.09 \\
Media mass $(\mathrm{kg})^{\mathrm{b}}$ & 1.7 & 5 & 25
\end{tabular}

a Total emission rate of $\mathrm{CO}_{2}$. For classrooms, the average age of occupant was taken to be 10 years, weight of $35 \mathrm{~kg}$, height of $1.4 \mathrm{~m}$, Dubois surface area of $1.1 \mathrm{~m}^{2}$, activity level of $1.2 \mathrm{met}$, and respiratory quotient of 0.83 . For bedroom and shelter-in-place, age was taken to be 35 years, weight of $60 \mathrm{~kg}$, height of $1.65 \mathrm{~m}$, Dubois surface area of 1.7, activity level of $1.2 \mathrm{met}$, and respiratory quotient of 0.83 .

${ }^{\mathrm{b}}$ Media packing density for both sorbents in the scrubber was taken to be $900 \mathrm{~kg} / \mathrm{m}^{3}$, as per soda lime manufacturer specifications. 
Table 2. Summary of physical and chemical properties of tested sorbents

Physical characterization

\begin{tabular}{llll}
\hline & & & Mass \\
Specific & Total & Avg. & median \\
surface & pore & pore & particle \\
area & volume & diameter & size $\left(\mathrm{d}_{50}\right)$ \\
{$\left[\mathrm{m}^{2} / \mathrm{g}\right]$} & {$\left[\mathrm{cm}^{3} / \mathrm{g}\right]$} & {$[\mathrm{nm}]$} & $(\mu \mathrm{m})^{\mathrm{d}}$ \\
\hline 27 & $7.2 \times 10^{-2}$ & 0.56 & 16 \\
5.6 & $8.7 \times 10^{-3}$ & 0.24 & 5.4 \\
15 & $3.9 \times 10^{-3}$ & 0.18 & 19 \\
7.1 & $1.6 \times 10^{-2}$ & 0.15 & $1000^{\mathrm{e}}$ \\
\hline
\end{tabular}

Sorbent

$\mathrm{MgO} \quad>91.5 \% \mathrm{MgO}, 4 \% \mathrm{LOI}^{\mathrm{b}}, 2 \% \mathrm{SiO}_{2}, 1.6 \% \mathrm{CaO}, 1 \% \mathrm{R}_{2} \mathrm{O}_{3}{ }^{\mathrm{c}}$

$\mathrm{Mg}(\mathrm{OH})_{2} \quad>99 \% \mathrm{MgOH}_{2}$

$\mathrm{Ca}(\mathrm{OH})_{2} \quad>99 \% \mathrm{Ca}(\mathrm{OH})_{2}$

Soda lime $\quad 85 \% \mathrm{Ca}(\mathrm{OH})_{2}, 10 \% \mathrm{H}_{2} \mathrm{O}, 3 \% \mathrm{KOH}, 2 \% \mathrm{NaOH}$

${ }^{\mathrm{a}}$ Chemical composition determined as described by Gall et al. [54]

${ }^{b} \mathrm{LOI}$ is loss on ignition, a determination of the amount of volatile substances within the sorbent composition.

${ }^{c} \mathrm{R}_{2} \mathrm{O}_{3}$ refers to the group of oxides generally consisting of $\mathrm{Al}_{2} \mathrm{O}_{3}, \mathrm{Fe}_{2} \mathrm{O}_{3}$, and $\mathrm{B}_{2} \mathrm{O}_{3}$, and are impurities in the sorbent composition.

${ }^{d}$ Median particle size of unground media reported from particle size analyzer

${ }^{\mathrm{e}}$ Median size of soda lime granules as reported by manufacturer. 
Table 3. Thermal decomposition of hydrate and carbonate phases within Mg-based sorbents

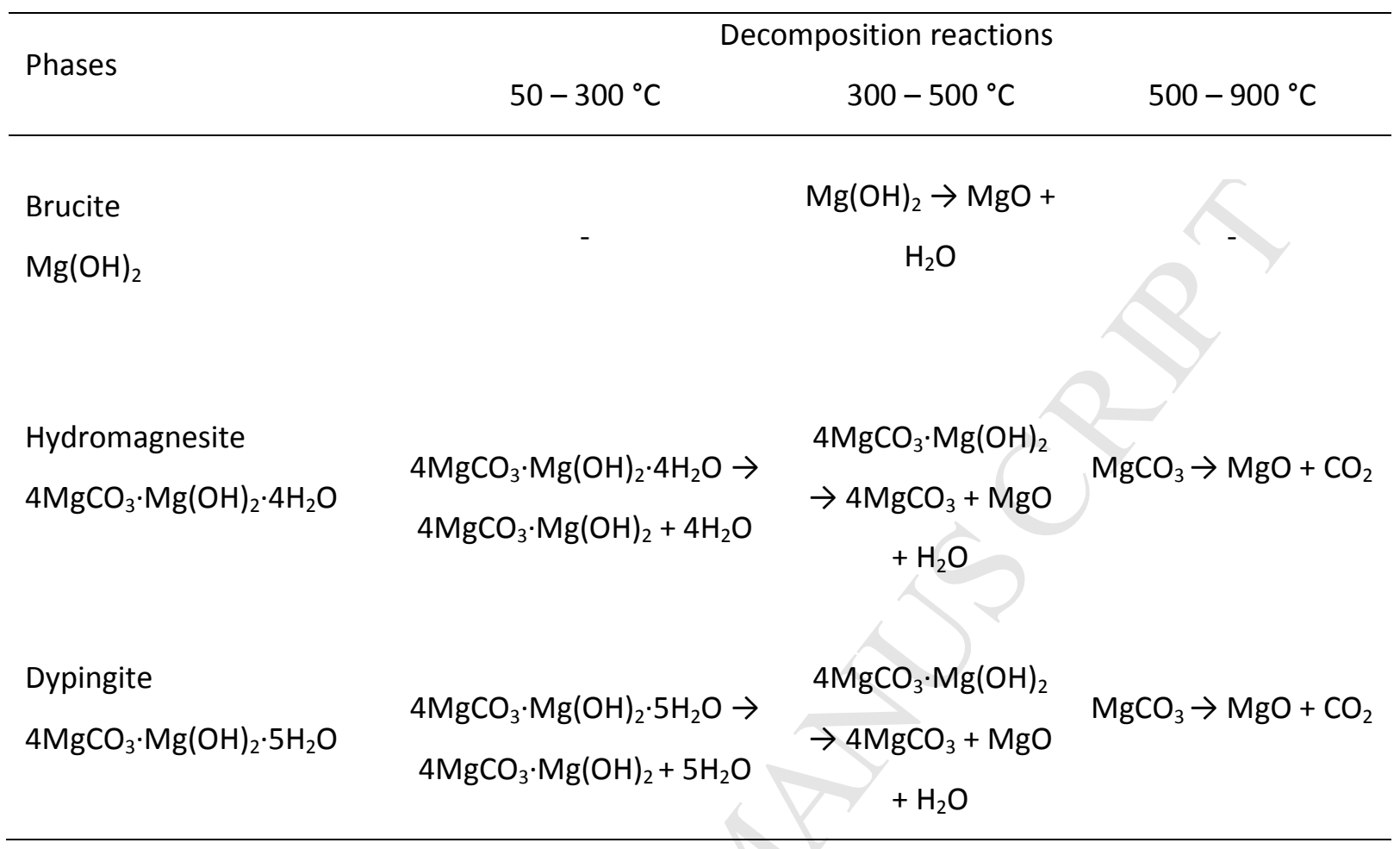




\section{ACCEPTED MANUSCRIPT}

Table 4. Summary of experimental conditions, reaction rate constants, $k$, and yields, $y$, for $\mathrm{CO}_{2}$ uptake experiments to soda lime and $\mathrm{Ca}(\mathrm{OH})_{2}$.

\begin{tabular}{|c|c|c|c|c|c|c|c|}
\hline \multirow[b]{2}{*}{ Sorbent } & \multirow[b]{2}{*}{$\begin{array}{l}\text { Experimental } \\
\text { condition }\end{array}$} & Temperature & $Q$ & $\begin{array}{c}\text { Contact } \\
\text { time }\end{array}$ & $\begin{array}{l}\text { Inlet } \\
{\left[\mathrm{CO}_{2}\right]}\end{array}$ & $\begin{array}{c}\text { Reaction rate } \\
\text { constant, } k\end{array}$ & Yield, $y$ \\
\hline & & {$\left[{ }^{\circ} \mathrm{C}\right]$} & {$[\mathrm{L} / \mathrm{min}]$} & {$[s]$} & [ppm] & $\begin{array}{l}{\left[\mathrm{m}^{3} \mathrm{~mol}\right.} \\
\left.\mathrm{CO}_{2}^{-1} \mathrm{~h}^{-1}\right]\end{array}$ & $\begin{array}{l}\mathrm{nol} \mathrm{CO} / \mathrm{mol} \\
\text { sorbent] }\end{array}$ \\
\hline \multirow{4}{*}{$\begin{array}{l}\text { Soda } \\
\text { lime }\end{array}$} & Dry packed & 26.1 & 1.8 & 0.28 & 1870 & 2.2 & 0.49 \\
\hline & bed & 25.2 & 2.8 & 0.18 & 1890 & 3.6 & 0.51 \\
\hline & \multirow{2}{*}{ Slurry } & 25.2 & 1.8 & 0.28 & 2100 & 1.9 & 0.74 \\
\hline & & 25.2 & 2.7 & 0.18 & 2110 & 1.6 & 0.79 \\
\hline \multirow{4}{*}{$\mathrm{Ca}(\mathrm{OH})_{2}$} & Dry packed & 25.2 & 1.8 & 0.28 & 2200 & 1.0 & 0.05 \\
\hline & bed & 24.8 & 2.8 & 0.18 & 2310 & 3.3 & 0.18 \\
\hline & \multirow{2}{*}{ Slurry } & 25.0 & 1.8 & 0.28 & 2200 & 1.6 & 0.65 \\
\hline & & 25.0 & 2.7 & 0.18 & 2200 & 2.4 & 0.65 \\
\hline
\end{tabular}


Table 5. Summary of sensitivity analysis of model output of indoor $\mathrm{CO}_{2}$ concentrations in three scenarios of active $\mathrm{CO}_{2}$ removal from indoor spaces.

\begin{tabular}{|c|c|c|c|c|}
\hline \multicolumn{5}{|c|}{ Shelter-in-place, Soda lime, Scrubber diameter $=0.12 \mathrm{~m}$} \\
\hline $\begin{array}{l}\text { Mass of } \\
\text { media }(\mathrm{kg})\end{array}$ & $\begin{array}{l}\text { Contact } \\
\text { time }(s)^{\#}\end{array}$ & $\begin{array}{l}\text { Pressure } \\
\text { drop }(\mathrm{Pa})^{\$}\end{array}$ & $\begin{array}{l}\text { Time to } \\
10,000 \mathrm{ppm} \\
\text { (h) }\end{array}$ & $\begin{array}{l}\int \text { exposure, } \\
0-8 \mathrm{~h} \text { (ppm-h) }\end{array}$ \\
\hline- & - & 0 & 1.9 & 139000 \\
\hline 0.9 & 0.09 & 157 & 6.5 & 46150 \\
\hline 1.3 & 0.14 & 226 & 8.4 & 27080 \\
\hline $1.7 *$ & 0.18 & 296 & 10.1 & 26200 \\
\hline 2.1 & 0.22 & 365 & 12.1 & 17780 \\
\hline 2.5 & 0.26 & 435 & 13.8 & 17080 \\
\hline
\end{tabular}

\begin{tabular}{|c|c|c|c|c|}
\hline \multicolumn{5}{|c|}{ Bedroom, Soda lime, Scrubber diameter $=0.25 \mathrm{~m}$} \\
\hline $\begin{array}{l}\text { Mass of } \\
\text { media }(\mathrm{kg})\end{array}$ & $\begin{array}{l}\text { Contact } \\
\text { time }(\mathrm{s})\end{array}$ & $\begin{array}{l}\text { Pressure } \\
\text { drop }(\mathrm{Pa})\end{array}$ & $\begin{array}{l}\text { Time to } 1,000 \\
\mathrm{ppm}(\mathrm{h})\end{array}$ & $\begin{array}{l}\int \text { exposure, } \\
0-8 \mathrm{~h}(\mathrm{ppm}-\mathrm{h})\end{array}$ \\
\hline- & - & 0 & 0.9 & 14730 \\
\hline 3 & 0.11 & 122 & 13 & 5370 \\
\hline 4 & 0.14 & 163 & 18 & 5000 \\
\hline 5 & 0.18 & 204 & 22 & 4820 \\
\hline 6 & 0.22 & 245 & 27 & 4730 \\
\hline 7 & 0.25 & 285 & 29 & 4730 \\
\hline
\end{tabular}

Classroom, Soda lime, Scrubber diameter $=0.45 \mathrm{~m}$

\begin{tabular}{lllll}
$\begin{array}{l}\text { Mass of } \\
\text { media }(\mathrm{kg})\end{array}$ & $\begin{array}{l}\text { Contact } \\
\text { time }(\mathrm{s})\end{array}$ & $\begin{array}{l}\text { Pressure } \\
\text { drop }(\mathrm{Pa})\end{array}$ & $\begin{array}{l}\text { Time to 1,000 } \\
\mathrm{ppm}(\mathrm{h})\end{array}$ & $\begin{array}{l}\text { S exposure, } \\
0-8 \mathrm{~h}(\mathrm{ppm}-\mathrm{h})\end{array}$ \\
\hline- & - & - & 0.4 & 11100 \\
15 & 0.11 & 170 & 4.0 & 7950 \\
20 & 0.14 & 337 & 6.6 & 7630 \\
$\mathbf{2 5}$ & $\mathbf{0 . 1 8}$ & $\mathbf{5 8 0}$ & $\mathbf{8 . 9}$ & $\mathbf{7 4 6 0}$ \\
30 & 0.22 & 910 & 11 & 7360 \\
35 & 0.25 & 1340 & 12 & 7340
\end{tabular}

\footnotetext{
\# Values for $k$ and $y$ at indicated contact time were determined by linearly interpolating/extrapolating from experimentally determined values.

\$Pressure drop was calculated using the Ergun equation [55] with an equivalent spherical particle diameter of $1 \mathrm{~mm}$ and a packed bed porosity of 0.55 .

* Conditions in bold are the 'base-case' conditions.
} 


\section{Figures}

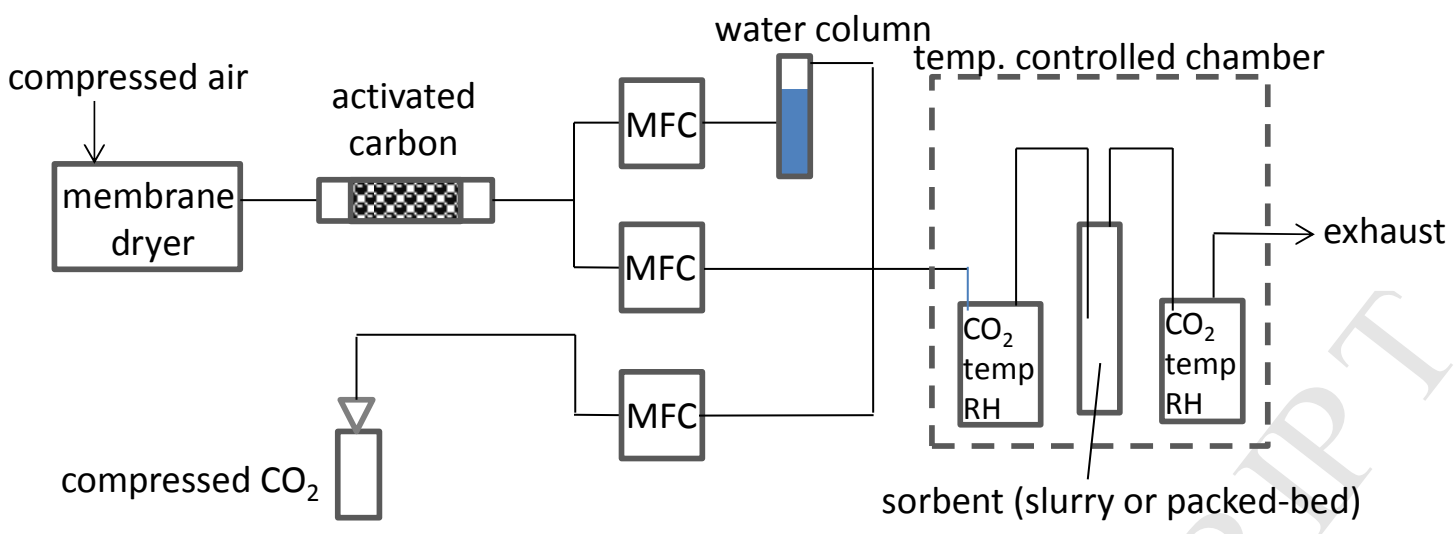

Figure 1. Schematic of laboratory apparatus used for carbonation experiments with controlled temperature, humidity and $\mathrm{CO}_{2}$ levels. $\mathrm{MFC}=$ mass flow controller, temp. $=$ temperature, $\mathrm{RH}=$ relative humidity. 


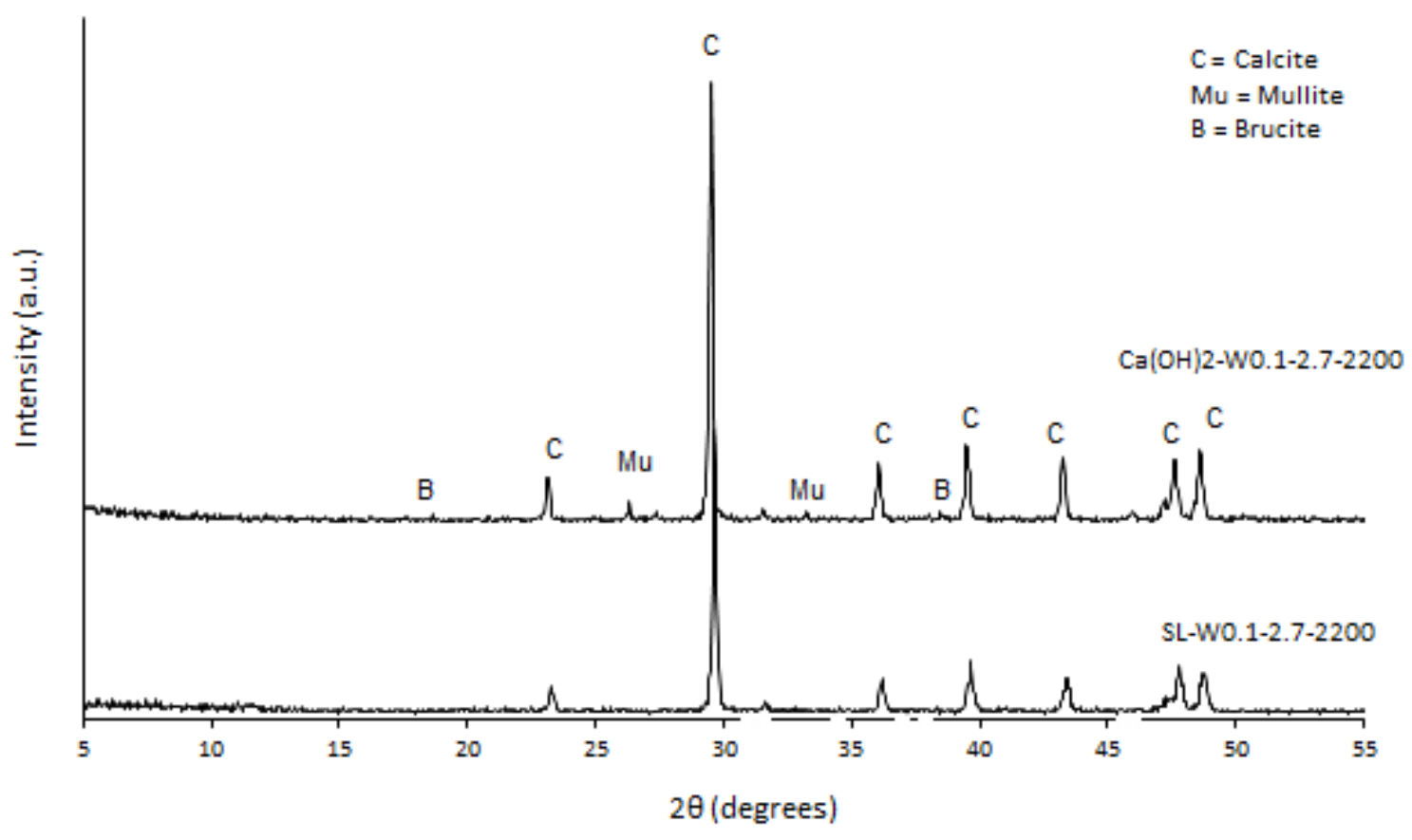

(a)

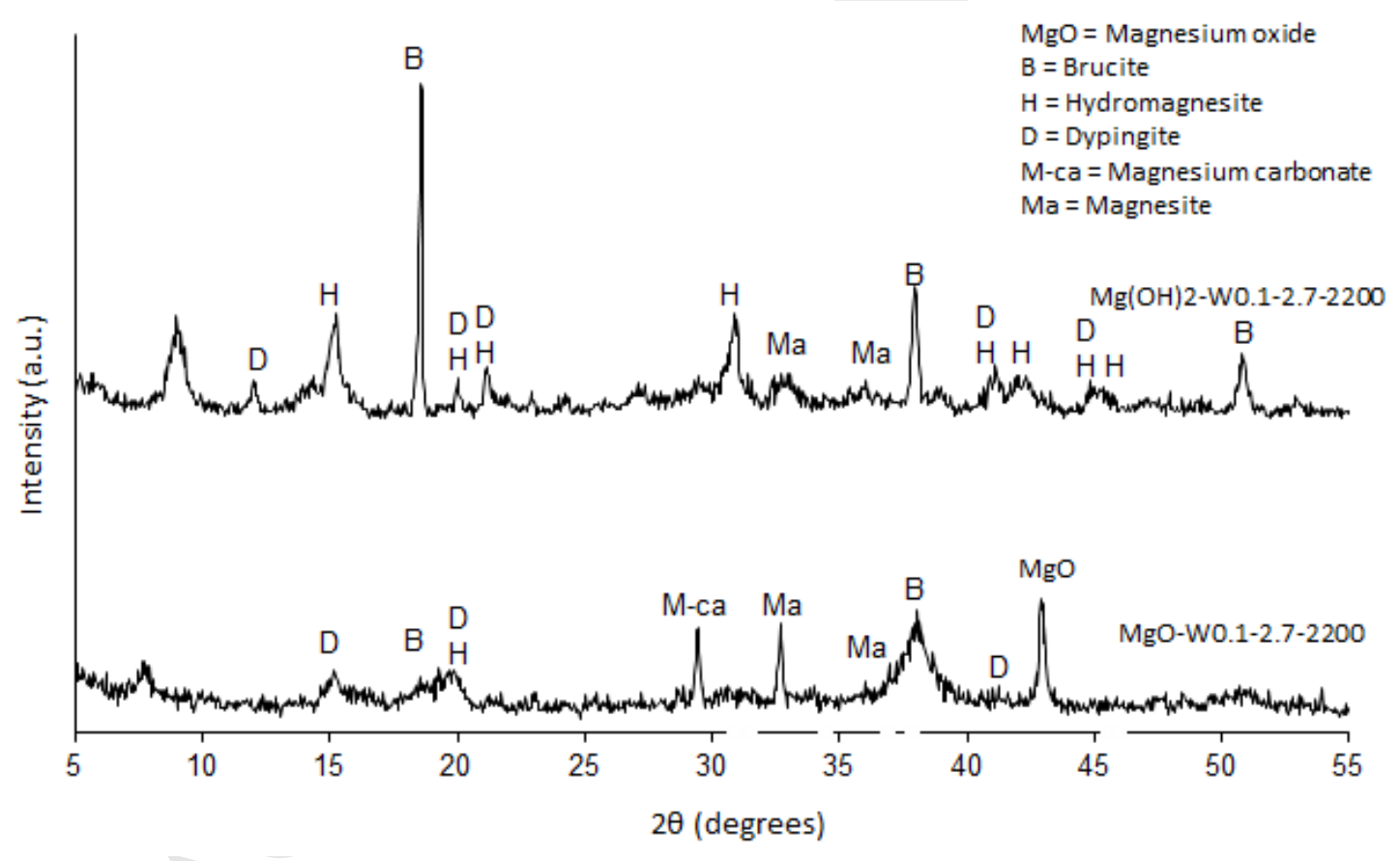

(b)

Figure 2. X-ray diffraction patterns of (a) $\mathrm{Ca}$ - and (b) $\mathrm{Mg}$-based sorbents after exposure to $\mathrm{CO}_{2}$. 


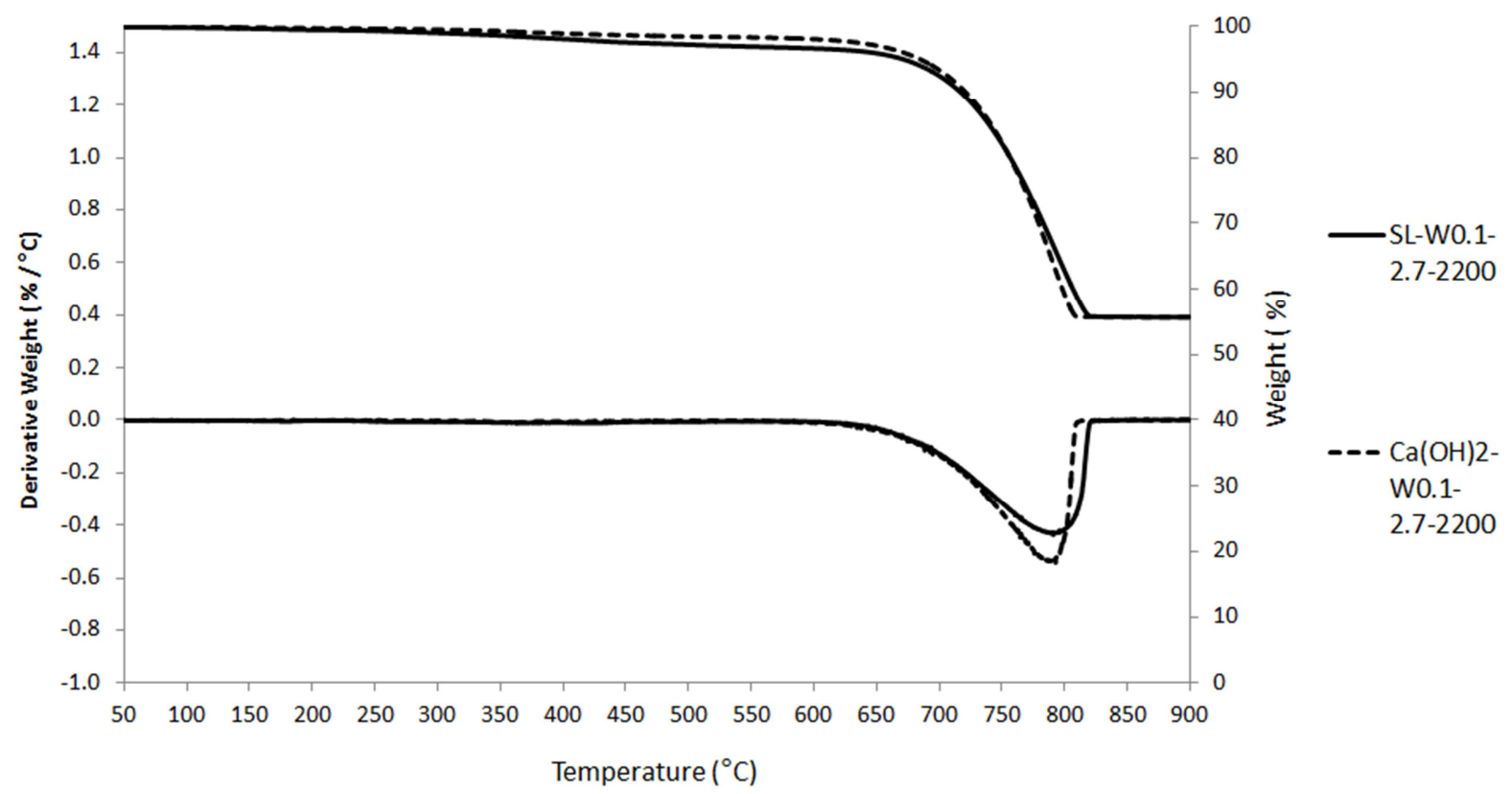

(a)

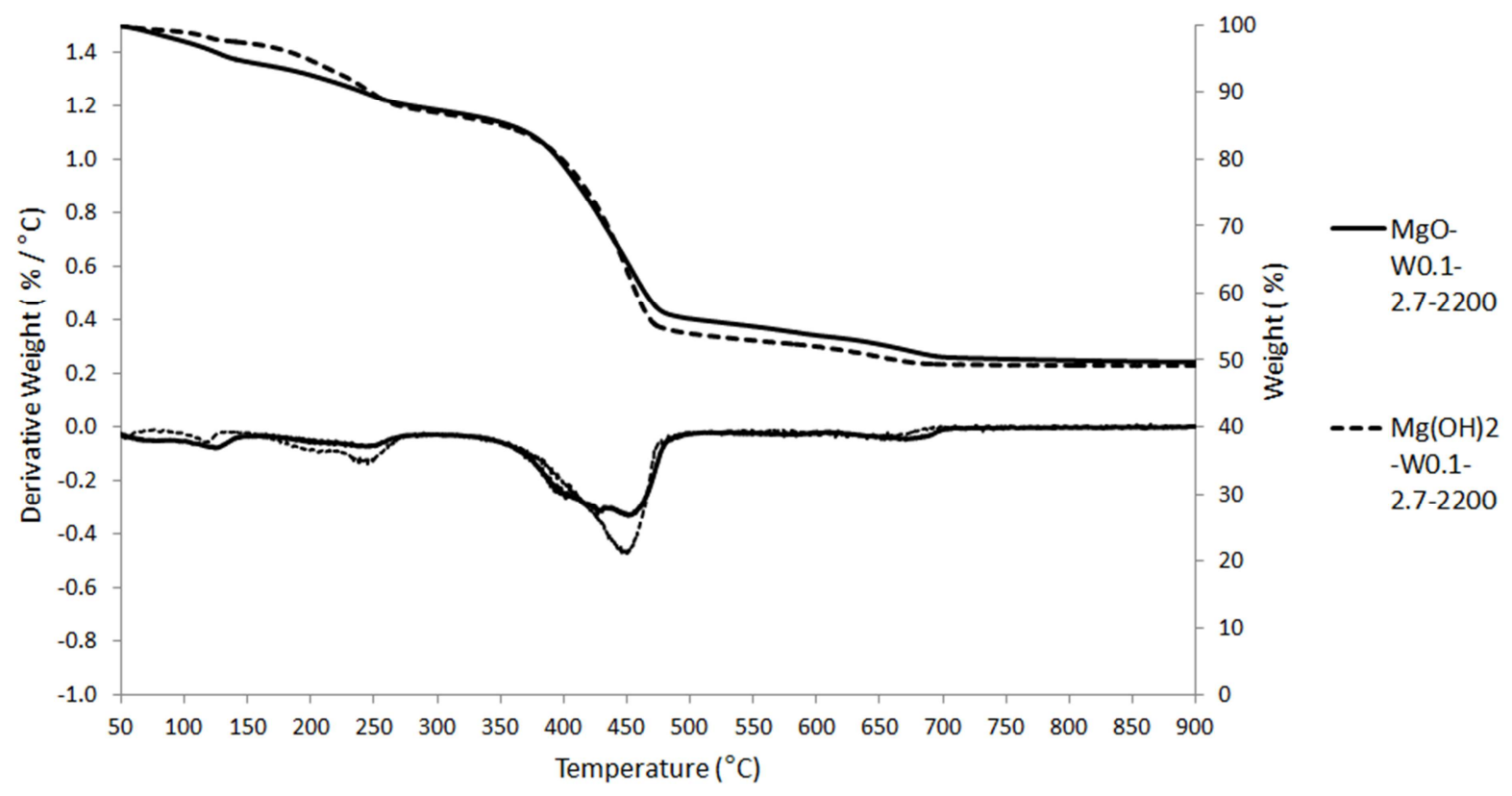

(b)

Figure 3. Thermogravimetric analysis graphs of (a) Ca- and (b) Mg-based sorbents (the primary $y$-axis (on the left) refers to the lower traces of derivative weight; the secondary $y$-axis (on the right) refers to the upper traces of percentage weight). 


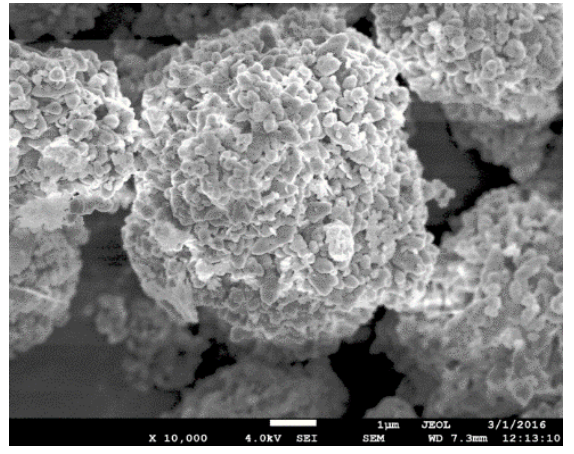

(a)

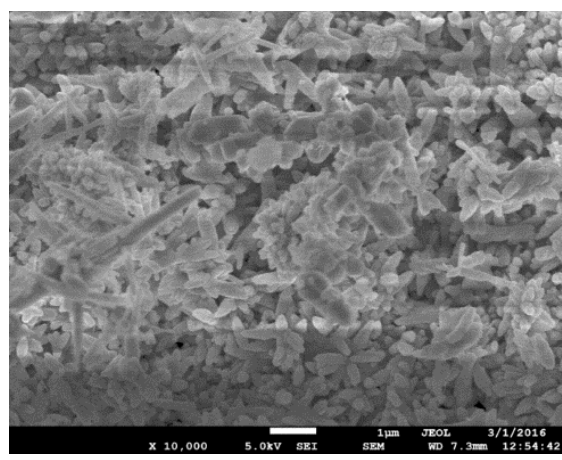

(c)

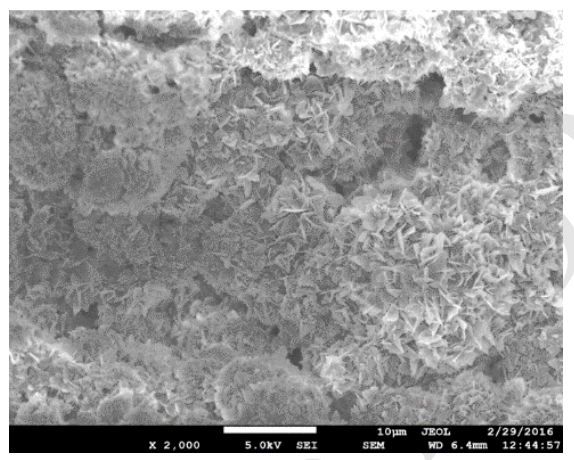

(e)

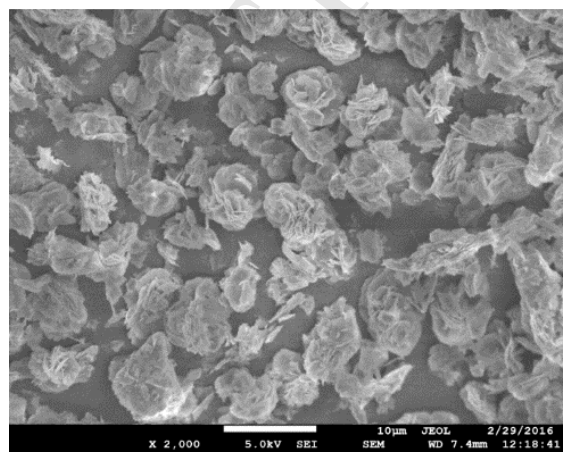

(g)

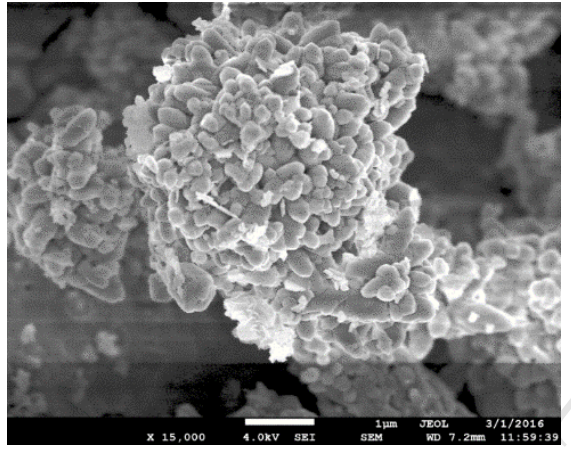

(b)

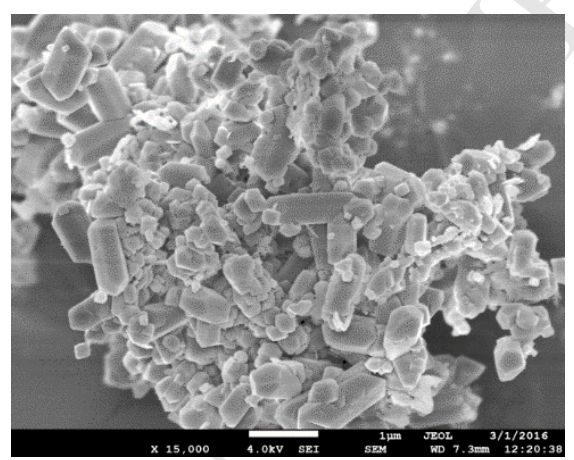

(d)

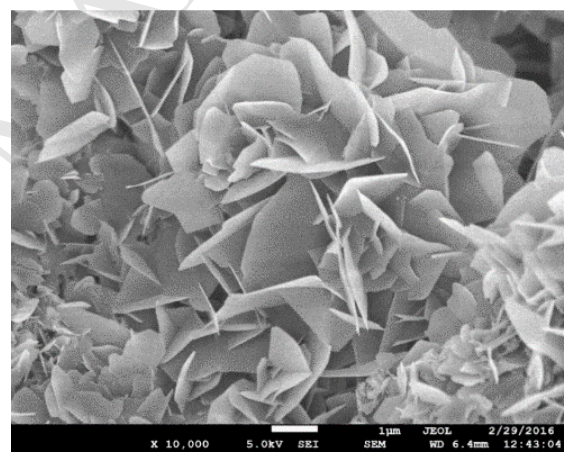

(f)

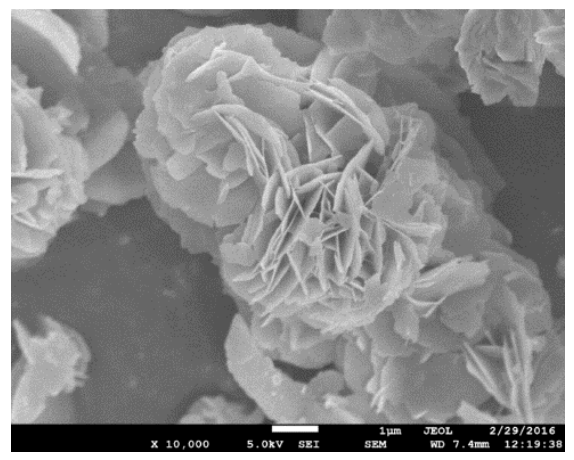

(h)

Figure 4. Scanning electron microscopy images of (a)-(b) SL-W0.1-2.7-2200, (c)-(d) $\mathrm{Ca}(\mathrm{OH})_{2}-\mathrm{W} 0.1-2.7-$ 2200, (e)-(f) MgO-W0.1-2.7-2200 and (g)-(h) Mg(OH) ${ }_{2}-\mathrm{W} 0.1-2.7-2200$. The white bar at the bottom of each photograph indicates the scale: $1 \mu \mathrm{m}(\mathrm{a}-\mathrm{d}, \mathrm{f}, \mathrm{h})$ or $10 \mu \mathrm{m}(\mathrm{e}, \mathrm{g})$. These images were acquired after exposure of the sorbents to $\mathrm{CO}_{2}$. 

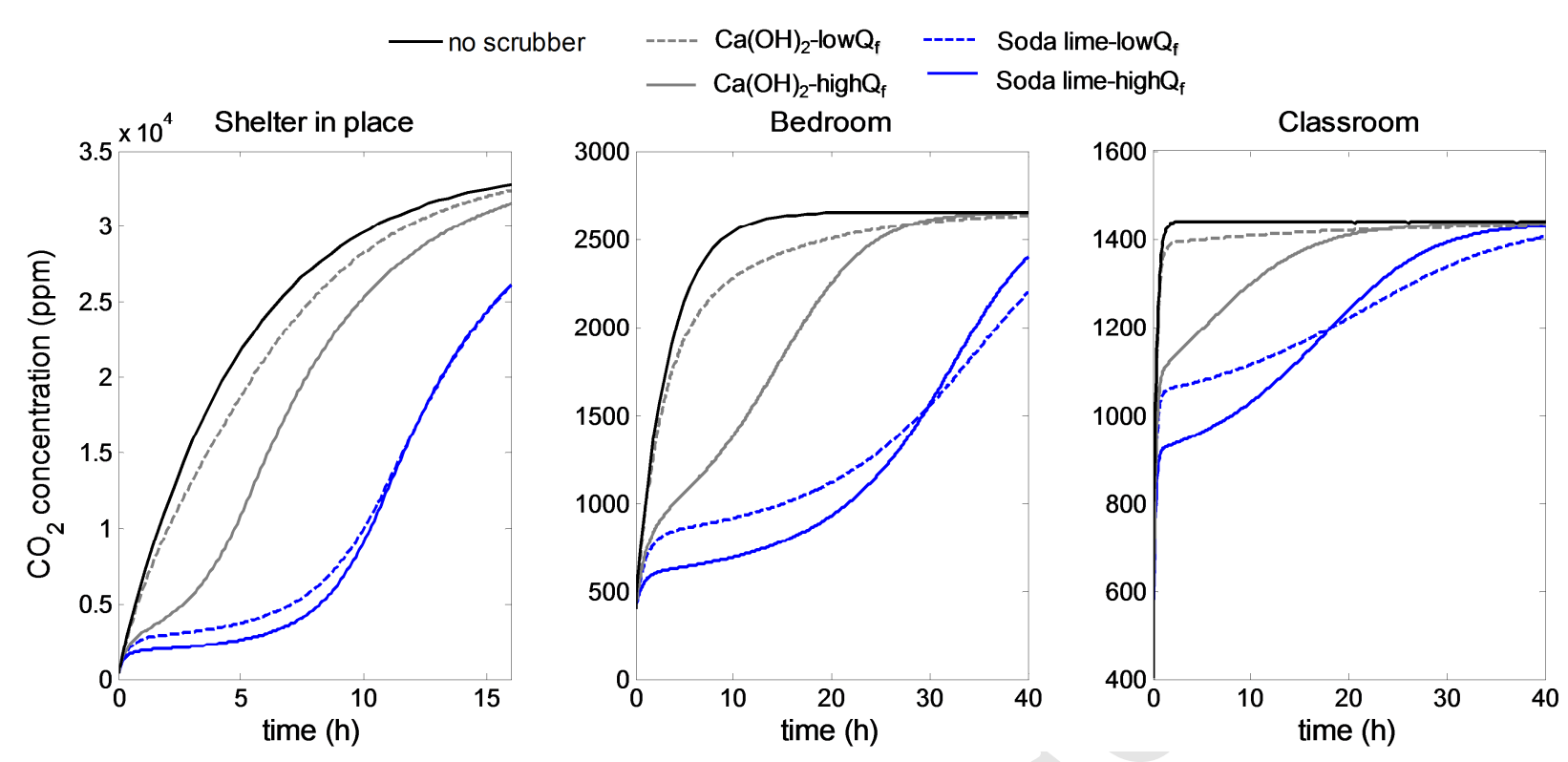

Figure 5. Modeled indoor $\mathrm{CO}_{2}$ concentrations for three hypothetical indoor environments: a shelterin-place facility, a bedroom and a classroom with and without the presence of an air cleaner that includes a $\mathrm{CO}_{2}$ scrubbing bed. Relevant built environment and air cleaner parameters for each of the three indoor environments are provided in Table 1. 'Low $Q_{f}^{\prime}$ refers to the low air cleaner flow rate condition, 'high $Q_{f}^{\prime}$ refers to the high air cleaner flow rate condition. 


\section{Highlights:}

- $\mathrm{CO}_{2}$ can accumulate in indoor spaces with low air exchange, e.g. in shelter-in-place

- Various Ca- or Mg- based sorbents are investigated as potential air cleaner media

- Ca containing sorbents carbonated under conditions relevant to indoor spaces

- Active removal may substantially reduce $\mathrm{CO}_{2}$ exposure in shelter-in-place facilities 